\title{
Mechanisms Underlying Bone Loss Associated with Gut Inflammation
}

\author{
Ke Ke ${ }^{1}$, Manoj Arra ${ }^{1}$ and Yousef Abu-Amer ${ }^{1,2, *}$ \\ 1 Department of Orthopaedic Surgery and Cell Biology and Physiology, Washington University School of \\ Medicine, St. Louis, MI 63110, USA; ke.ke@wustl.edu (K.K.); arram@wustl.edu (M.A.) \\ 2 Shriners Hospital for Children, St. Louis, MI 63110, USA \\ * Correspondence: abuamery@wustl.edu; Tel.: +1-314-362-0335
}

Received: 29 October 2019; Accepted: 10 December 2019; Published: 15 December 2019

\begin{abstract}
Patients with gastrointestinal diseases frequently suffer from skeletal abnormality, characterized by reduced bone mineral density, increased fracture risk, and/or joint inflammation. This pathological process is characterized by altered immune cell activity and elevated inflammatory cytokines in the bone marrow microenvironment due to disrupted gut immune response. Gastrointestinal disease is recognized as an immune malfunction driven by multiple factors, including cytokines and signaling molecules. However, the mechanism by which intestinal inflammation magnified by gut-residing actors stimulates bone loss remains to be elucidated. In this article, we discuss the main risk factors potentially contributing to intestinal disease-associated bone loss, and summarize current animal models, illustrating gut-bone axis to bridge the gap between intestinal inflammation and skeletal disease.
\end{abstract}

Keywords: gut inflammation; mucosal immunity; bone loss; risk factors; animal models; osteoclasts

\section{Introduction}

The intestinal immune system is primarily involved in controlling and limiting mucosal immune responses to enteric and ingested bacterial antigens, through the actions of gut-associated lymphoid tissue (GALT) [1]. GALT is also involved in mounting appropriate immune responses to pathogenic bacteria in order to protect the body. However, inappropriate GALT activity results in a variety of unnecessary or disrupted immune activity which could manifest as functional disorders within or beyond the gastrointestinal (GI) tract [2-4]. Inflammatory bowel disease (IBD) is one such systemic, bowel-centric condition with chronic immune activation and inflammation within the GI tract that to this date remains poorly understood. Ulcerative colitis (UC) and Crohn's disease (CD) are two distinct forms of IBD, both characterized by a multifactorial, incompletely known etiology involving genetic components, environmental factors, and altered gut microbiota (GM) [5]. The extra-intestinal manifestation in IBD patients involves development of disease in other organs, including the joints, skin, or eyes [6], that can lead to significant co-morbidities and loss of quality of life.

Patients with GI disease, especially IBD, are at a significantly higher risk of developing skeletal disease, such as osteoporosis (OP) (17-41\% of patients) or osteopenia ( $22-77 \%$ of patients), and other enteropathic arthropathies [7-10]. OP is a systemic skeletal disease characterized by significantly reduced bone mass/mineral density (BMD) and deterioration of bone microarchitecture [11]. Cases of OP are classified as primary or secondary. Primary OP is the most common and prevalent form, including juvenile, postmenopausal and senile OP. The causes of secondary OP are vast and attributed to underlying diseases, including hematological diseases, GI disease, vitamin deficiency, solid organ transplantation, and chronic medication [12]. The main therapies for treating OP target bone remodeling involve either inhibiting the bone resorbing osteoclasts (OCs) or promoting the activity of bone forming 
osteoblasts (OBs) [13]. Although bone alterations in IBD patients is considered to be one of the most prevalent forms of secondary OP, the underlying pathological mechanisms in IBD patients are complex and still relatively unknown. In addition to low bone mass, GI disease is also characterized by its inflammatory joint disease with features similar to psoriasis, rheumatoid arthritis, and connective tissue diseases [14]. Certain extra-intestinal manifestation on joints is related to disease activity and specific location in the gut [10]. Overall, bone and joint conditions cause severe morbidity and even mortality in patients with gut diseases such as IBD, requiring a greater understanding of the connection between these two systems. In this review, we discuss and summarize the current known knowledge underlying the mechanism of gut inflammation-mediated skeletal dysfunction in humans.

\section{Main Risk Factors of Bone Deterioration in Patients with GI Disease}

Skeletal disorders present in GI disease such as IBD are thought to result from a complex interplay of environmental and host factors.

\subsection{Genetic Factors}

A complex genetic background could be a common feature in the etiology of gut inflammation and bone loss. Several genomic studies including polymorphic analysis have been investigated to show some of the susceptibility loci overlap for both diseases, including but not limited to Interleukin (IL)-1 $\beta$, TNFSF11 (Receptor Activator of Nuclear Factor Kappa-B Ligand, RANKL), TNFRSF11B (Osteoprotegerin, $O P G$ ), IL-6, and Vitamin-D receptor (VDR).

\subsubsection{IL-1 $\beta$}

IL-1 $\beta$ is a well characterized pro-inflammatory cytokine implicated in various inflammatory disorders. The IL- $1 \beta$ locus has been implicated in genetic susceptibility to IBD $[15,16]$. IL- $1 \beta$ is a well-known player in bone loss in RA patients that promotes osteoclastogenesis [17]. Furthermore, Nemetz et al. showed an increased risk of bone loss in IBD patients with IL-1B polymorphism (IL1B-511, rs16944) associated with hyper secretion of IL-1 $\beta$ [18]. Treatment of IBD patients diagnosed with systemic onset juvenile idiopathic arthritis with IL-1 $\beta$ antagonists showed well-controlled systemic juvenile idiopathic arthritis (sJIA) symptoms at time of diagnosis of IBD [19].

\subsubsection{RANKL/OPG}

RANKL and OPG are two competing molecules critical for the process of bone remodeling. RANKL promotes osteoclastogenesis by binding to RANK and activating downstream signal cascades such as the nuclear factor kappa-B (NF-kB) pathway. OPG acts as a decoy for RANKL and can competitively interfere with its binding to RANK, thus, creating a fine tuned balance between bone resorption and formation. Altered RANKL/OPG system has been described to be associated with a lower BMD found in IBD patients. Moschen et al. paradoxically showed elevated plasma OPG in IBD patients as well as high levels of OPG released from the inflamed colonic mucosa [20]. However, a negative correlation between OPG plasma levels and spine and femoral neck BMD were found in osteoporotic IBD patients. Although plasma levels of soluble RANKL is not changed, an increased numbers of RANKL+ cells were noted in the lamina muscularis of IBD patients [20]. It is possible that in these patients, OPG levels are elevated as a compensatory mechanism in order to counteract the effects of pro-inflammatory cytokines. In addition, it is still unclear how local versus systemic effects of RANKL and OPG differ. Taranta et al. [21] showed an increased RANKL/OPG ratio and lower expression of the OC inhibitory cytokines IL-12 and IL-18 [22] in the sera of untreated celiac patients, pointing to potential peripheral blood mononuclear cell-derived impact on osteoclastogenesis. Interestingly, a recent polymorphism study found that the c.-223T allele of the OPG-encoding gene TNFRS11B was twice more frequent in CD patients than among controls, though the average level of $O P G$ is not significantly different from controls. In UC patients, OPG levels were significantly lower, suggesting that low OPG levels may be associated with bone loss in UC, but not correlated 
with c.-223C $>\mathrm{T}$ (rs2073617) polymorphism in the TNFRS11B gene [23]. Furthermore, RANKL has gut-intrinsic functions by acting as a critical factor for the development of $\mathrm{M}$ cells [24], which are involved in antigen sampling and modulation of the gut immune response. This gut-produced RANKL may escape into systemic circulation and also have impacts on the cells of the skeletal system. Therefore, a further understanding of the roles of local and systemic RANKL/OPG on bone loss in the context of IBD is required.

\subsection{3. $I L-6$}

IL-6 is a cytokine that has both pro-inflammatory and anti-inflammatory properties, though it is widely accepted as a pro-osteoclastogenic factor. IL- 6 expression is driven by various pathways, including the NF- $\mathrm{KB}$ and MAPK pathways, among others. The literature concerning genetic variations of IL-6 expression in predisposing OP in IBD patients appears contradictory. Genetic variation analysis identified IL-6 gene as being associated with increased risk of bone loss in IBD patients [25], especially with $C D$ [26]. However, a previous study from the Schulte group showed a genetic response to stress in IBD patients could not support IL-6 as a major predictor for the degree of bone disease. This coincides with several contradictory findings regarding the role of IL-6 in modulating osteoclasts and osteoblasts in bone remodeling. The role of IL-6 in gut-bone axis requires further study to resolve these conflicting findings.

\subsubsection{Vitamin D Receptor (VDR)}

Vitamin D is hydrophobic nutrient critical for various body processes and skeletal health. Vitamin $\mathrm{D}$ can be produced endogenously in the body through the function of melanocytes or can be obtained nutritionally. Vitamin D is modified to its active form, and its binding to the intracellular VDR activates its downstream functions. A recent study from Szymczak-Tomczak et al. [27] revealed that although IBD patients did not display differences in serum $25(\mathrm{OH}) \mathrm{D}$ in comparison to control subjects, a protective effect of the VDR gene TaqI (rs731236, c.1057T >C) allele on BMD was seen in IBD patients and controls. Particularly, a higher femoral neck bone mass was found to be associated with tt genotypes of VDR gene in UC patients [27]. Another study based on North Indian postmenopausal women showed the frequency of TT genotypes was highly expressed in osteoporotic women compared to controls with normal BMD [28]. The role of VDR in the modulation of bone health is under intense debate $[29,30]$ due to a number of cohort effects (age, district, genetic background, disease activity, etc.).

\subsection{Microbiota}

The microbiome of an individual consists of more than 1000 microbial species including bacteria and single-celled eukaryote. Homeostatically, the gut microbiota (GM) provides colonization resistance and regulates immune balance bidirectionally within the epithelial barrier and tissue environment, to protect the host from invading pathogens [31]. Perturbed balance in microbial composition has been postulated to be associated with compromised immunity within the gut, and an increased susceptibility to the development of enteropathic arthropathies, such as spondyloarthropathy and psoriatic arthritis [32-34]. A recent cross-sectional study displayed an increased abundance in the Clostridiaceae family of bacteria was shared by patients with IBD-associated arthropathy and RA, potentially due to the effects of bowel surgery history [35]. Fecal microbiota study reveals patients with spondyloarthritis (SpA) had a significant abundance of Ruminococcus gnavus, compared with both RA and healthy controls, correlated with a history of IBD in patients [36]. This emerging evidence suggests a potentially common microbial link for inflammatory arthritis and gut inflammation. However, it remains unknown whether enteropathic arthropathies are secondary to inflammation induced by gut dysbiosis. 


\subsection{Vitamin D Homeostasis}

Among IBD patients, reduced BMD or osteopenia is associated with a lack of nutrient intake and defective nutrient utilization, mainly as a result of vitamin deficiency, insufficient calcium uptake and ultimately malabsorption due to destruction of intestinal villi. Surveys on dietary habits and nutrient intake showed lower bone density in malnourished IBD patients [37] especially when undergoing a flare. The gut, bone, and kidney are the major players regulating calcium homeostasis. The calcium homeostatic cycle is regulated systemically and locally by vitamin D and parathyroid hormone (PTH) [37]. Vitamin D is absorbed primarily in the duodenum of the small intestine through dietary consumption, as well as de novo synthesis in the skin by UV irradiation. Activity of 1, 25-dihydroxyvitamin D (Vitamin D3), the biologically active form of vitamin D, is mainly functionally mediated by the vitamin D receptor (VDR) [38]. Vitamin D increases calcium absorption in the gut, prevents calcium loss in the nephrons of the kidney, and inhibits bone resorption overall. Systemic vitamin D level is reported to be positively correlated with colonic VDR expression in healthy subjects [39]. However, IBD patients showed a reduced expression of epithelial VDR in inflamed large bowel [40,41], indicating VDR may work as an important gatekeeper maintaining mucosal barrier function. GWAS analysis of the gut microbiota identified a significant association of bacterial abundance and VDR loci [42]. Although recent studies on correlation between VDR and its relationship with IBD-associated bone loss are still in debate [27-30], targeting local expression of VDR, particularly in the epithelial barrier, might be a potential solution to manipulate vitamin D homeostasis in both IBD patients and OP subjects. Del Pinto et al. performed meta-analysis to display that UC patients possess a greater association with vitamin D deficiency than patients with CD [43]. Several studies showed pediatric and adolescent populations with IBD possess greater vitamin D deficiency than healthy subjects [43-46]. The trend towards decreased vitamin D-VDR activity likely partially contributes to the poor bone health in pediatric IBD patients $[47,48]$, although contrasting results have been shown [49]. High risks for bone disease in IBD patients are partly due to impaired intestinal calcium absorption [37]. Since vitamin D/VDR works as crucial players in maintaining gut immune function, especially through regulating gut barrier potential [50], increased production of proinflammatory cytokines due to vitamin D deficiency may also synergistically increase prevalence of both intestinal immune response and malabsorption.

\subsection{Medication}

Anti-inflammatory and immunosuppressive drugs are commonly prescribed to IBD patients for induction and maintenance of remission during treatment. Corticosteroids, such as glucocorticoids, are the standard treatment for IBD for their rapid effect on reducing symptoms [51]. However, long term and/or high dose consumption of systemic corticosteroids results in rapid bone loss, accompanied with lower BMD and increased risk of fracture [52]. Excessive glucocorticoids consumption disrupts bone remodeling through increasing OB apoptosis, elevating RANKL/OPG levels, and stimulating osteoclastogenesis [53]. Additionally, glucocorticosteroid treatment significantly increases serum fibroblast growth factor-23 level in pediatric patients with idiopathic nephrotic syndrome [54] and receiving kidney transplant [55]. Elevated systemic fibroblast growth factor-23 level was also found to be associated with low BMD in childhood IBD [56], suggesting importance of management of steroids treatment in IBD patients. Prospective clinical trials by introduction of alternative immunosuppressive, such as azathioprine, and anti-tumor necrosis factor (TNF) agents, including infliximab, showed a superior therapeutic effect in IBD patients; however, the association of BMD, drug therapy, and the prevalence of disease activity need to be analyzed further [9]. 


\section{Animal Models of Gut Inflammation-Induced Bone Loss}

Recent studies characterizing bone loss in animal models of intestinal inflammation, demonstrated that gut residing immune cells as well as inflammatory mediators such as inflammatory cytokines, signaling proteins and endocrine factors, contributed to GI-disease-induced bone destruction. To better understand the interaction between bone loss and immune system in gut disease, various animal models of gut disease have been utilized. Generally, animal models of gut inflammation are mainly established using genetic modification, gut-residing microbiome modification, immune cell transfer (transferring T effector cells into immune-deficient mice), or chemical induction (e.g., TNBS, DSS). These models can then be used to study the effect on the skeletal system. A list of selected animal models indicating skeletal abnormalities seen in gut inflammation is summarized in Table 1.

Table 1. Animal models indicating linkage between gut-bone axis signaling.

\begin{tabular}{|c|c|c|c|c|}
\hline \multicolumn{5}{|c|}{ Models Based on Genetic Modification } \\
\hline Animal Strains & GI Phenotype & Skeletal Phenotype & $\begin{array}{l}\text { Systemic and Other } \\
\text { Organ Phenotype }\end{array}$ & Reference \\
\hline$H L A-B 27 \mathrm{Tg}$ rats & $\begin{array}{c}\text { IBD } \\
\text { dysbiosis }\end{array}$ & $\begin{array}{c}\text { Spondylarthritis; } \\
\text { RANKL/OPG } \uparrow \\
\text { osteoclastogenesis } \uparrow \\
\end{array}$ & $\begin{array}{l}\text { circulating monocytes } \uparrow \\
\text { serum OCN, PINP: n.s. }\end{array}$ & {$[57-61]$} \\
\hline VDR-/- mice & $\begin{array}{l}\text { normal intestine; } \\
\text { colonic } 8 \text {-OHdG } \uparrow \\
\mathrm{Ca}^{2+} \text { absorption } \uparrow\end{array}$ & $\begin{array}{l}\text { rickets, osteomalacia; } \\
\text { femur BMD and MAR } \downarrow\end{array}$ & $\begin{array}{c}\mathrm{BW} \downarrow \\
\text { Serum OCN, 25-OH-D } \\
\mathrm{Ca}^{2+} \downarrow \\
1,25(\mathrm{OH})_{2} \mathrm{D}_{3} \text { and } \mathrm{PTH} \uparrow\end{array}$ & [62-65] \\
\hline$V d r(\triangle I E p C)$ mice & $\begin{array}{c}\text { intestinal } \mathrm{Ca}^{2+} \\
\text { absorption } \downarrow\end{array}$ & $\begin{array}{c}\text { osteopenia; bone turnover } \\
\uparrow ; \text { BV/TV, Ct.Th., Tb.N., } \\
\text { Tb.Th. } \downarrow \text {; mineralization } \\
\text { and skeletal Ca }{ }^{2+} \downarrow ; \\
\text { RANKL/OPG } \uparrow\end{array}$ & $\begin{array}{c}\text { Serum } \mathrm{PTH}, \\
1,25(\mathrm{OH})_{2} \mathrm{D}_{3}, \mathrm{CTX} \text {, and } \\
\mathrm{OCN} \uparrow\end{array}$ & {$[66,67]$} \\
\hline IL-10-/- mice & colitis & $\begin{array}{c}\text { bone mass, Tb.Th. and } \\
\text { Tb.N. } \downarrow \\
\text { bone formation } \downarrow \\
\text { \%Th17-TNF } \alpha+\text { in BM } \uparrow\end{array}$ & $\begin{array}{l}\text { serum OCN } \downarrow \\
\text { renal Klotho } \downarrow\end{array}$ & {$[68-70]$} \\
\hline IL-2-/- mice & $\begin{array}{l}\text { colitis; colonic } \\
\text { dendritic cells, } \\
\text { macrophages, and } \\
\text { antigen-presenting } \\
\text { CD4+T cells } \uparrow\end{array}$ & $\begin{array}{c}\text { osteopenia; bone } \\
\text { formation } \downarrow, \text { OC.N. } \uparrow, \text { BM } \\
\text { monocytes } \uparrow, \text { RANKL, } \\
\text { OPG } \uparrow\end{array}$ & $\begin{array}{l}\text { serum RANKL, OPG, } \\
\text { MCP-1, IL-6, TNF } \alpha \text {, and } \\
\text { interferon-gamma } \\
(\text { IFN } \gamma) \uparrow\end{array}$ & {$[71,72]$} \\
\hline $\operatorname{Tn} f^{\triangle A R E}$ mice & CD-like IBD & spontaneous polyarthritis & serum TNF $\uparrow$ & [73] \\
\hline $\begin{array}{c}\text { gp130 } \Delta S T A T / \triangle S T A T \\
\text { mice }\end{array}$ & ulceration & $\begin{array}{c}\text { chronic synovitis; } \\
\text { degraded articular } \\
\text { cartilage; chondrocyte } \\
\text { differentiation } \downarrow \\
\text { trabecular BV/TV n.s. }\end{array}$ & N/A & {$[74,75]$} \\
\hline $\begin{array}{c}\text { gp130 Y757F Y757F } \\
\text { mice }\end{array}$ & gastric cancer & $\begin{array}{c}\mathrm{BV} / \mathrm{TV} \downarrow \\
\text { bone turnover } \uparrow\end{array}$ & N/A & [75] \\
\hline $\begin{array}{c}\text { STAT3-CFF } \\
\left(\text { Tie2 } 2^{\text {Cre+ }}-\text { Stat } 3^{f l f f l}\right) \\
\text { mice }\end{array}$ & $\begin{array}{c}\text { CD-like IBD, } \\
\text { immune cell } \\
\text { infiltration TNF } \alpha \uparrow, \\
\text { INF } \gamma \uparrow\end{array}$ & $\begin{array}{c}\text { BV, Tb. Th., and Tb.N. } \downarrow \\
\text { OC.N. } \uparrow \\
\text { mitochondrial dysfunction } \\
\text { in stem/progenitor cells } \\
\text { and ROS } \uparrow\end{array}$ & N/A & {$[76,77]$} \\
\hline A20 myel-KO mice & less stable microbiota & $\begin{array}{c}\text { severe polyarthritis } \\
\text { macrophage NF- } \mathrm{B} B \\
\text { activity and TNF } \uparrow \\
\text { osteoclastogenesis } \uparrow\end{array}$ & $\begin{array}{c}\text { serum inflammatory } \\
\text { cytokines } \uparrow \\
\text { Spleen and inguinal } \\
\text { lymph nodes Th17 } \uparrow\end{array}$ & {$[78,79]$} \\
\hline
\end{tabular}


Table 1. Cont.

\begin{tabular}{|c|c|c|c|c|}
\hline$I K K 2 c a^{I E C}$ & $\begin{array}{l}\text { mild gut inflammation } \\
\text { at } 8-10 \text { weeks, } \\
\text { inflammatory } \\
\text { cytokines in IECs and } \\
\text { ILC3 } \uparrow\end{array}$ & $\begin{array}{c}\mathrm{BV} / \mathrm{TV} \downarrow \\
\text { Osteoclastogenesis } \uparrow\end{array}$ & $\begin{array}{l}\text { serum inflammatory } \\
\text { cytokines and CTX } \uparrow\end{array}$ & [80-82] \\
\hline FXR-/- mice & $\begin{array}{l}\text { barrier dysfunction } \\
\text { apoptotic goblet cells }\end{array}$ & $\begin{array}{c}\text { BFR, Tb. BV. and Tb. Th. } \downarrow \\
\text { OB differentiation } \downarrow \\
\text { osteoclast generation } \uparrow\end{array}$ & N/A & [83-85] \\
\hline$m d r 2-/-$ mice & $\begin{array}{l}\text { barrier dysfunction; } \\
\text { dysbiosis }\end{array}$ & $\begin{array}{c}\text { osteopenia } \\
\text { trabecular bone mass } \downarrow\end{array}$ & N/A & {$[86,87]$} \\
\hline \multicolumn{5}{|c|}{ Models Based on Dysbiosis-Associated Gut Inflammation } \\
\hline Animal Strains & GI Phenotype & Skeletal Phenotype & $\begin{array}{l}\text { Systemic and Other } \\
\text { Organ Phenotype }\end{array}$ & Reference \\
\hline GF mice & $\begin{array}{c}\text { serotonin } \uparrow \\
\text { CD4+ T cells } \downarrow \\
\text { TNF } \alpha \downarrow\end{array}$ & $\begin{array}{l}\text { BV/TV, Tb.N. and BFR } \uparrow \text {; } \\
\text { Tb.Sp. and OC.N. } \downarrow \\
\text { BM-CD4+T cells, Th17, } \\
\text { TNF } \alpha \text { and IL-6 } \downarrow \\
\text { BM-OC precursor } \downarrow \text { OC } \\
\text { fusion } \downarrow\end{array}$ & $\begin{array}{c}\text { serum } \mathrm{OCN}, \mathrm{CTX}, \mathrm{Ca}^{2+}, \\
\text { serotonin and TNF } \downarrow \\
\text { IGF } \uparrow\end{array}$ & {$[88,89]$} \\
\hline ConvD-GF & 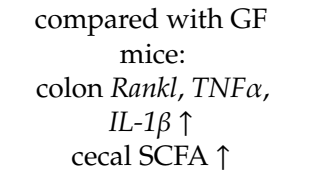 & $\begin{array}{c}\text { compared with GF mice: } \\
\text { femur length } \uparrow \\
\text { Periosteal area } \uparrow \\
\text { endosteal area } \uparrow \\
\text { IGF-1 and RANKL in BM } \uparrow\end{array}$ & $\begin{array}{c}\text { serum CTX-I, PINP: n.s. } \\
\text { serum IGF- } 1 \uparrow \\
\text { muscle IGF- } 1 \downarrow \\
\text { fat pad } \uparrow\end{array}$ & [90] \\
\hline \multicolumn{5}{|c|}{ Models Based on Chemical Induction } \\
\hline Animal Strains & GI Phenotype & Skeletal Phenotype & $\begin{array}{l}\text { Systemic and Other } \\
\text { Organ Phenotype }\end{array}$ & Reference \\
\hline TNBS & $\begin{array}{l}\text { crypt loss, cellularity, } \\
\text { and edema }\end{array}$ & $\begin{array}{c}\text { BV/TV, BFR and osteoid } \\
\text { surface } \downarrow \text { OC.S } \uparrow \\
\% \text { of TNF } \alpha+, \text { IL- } 6+, \\
\text { RANKL+, and OPG+ } \\
\text { osteocytes } \downarrow \\
\% \text { of sclerostin+ and IGF+ } \\
\text { osteocyte } \uparrow\end{array}$ & N/A & [91] \\
\hline TNBS & $\begin{array}{c}\text { Severe colitis; } \\
\text { colon TNF, IFN } \gamma \text {, IL-17, } \\
\text { IL- } 1 \beta \uparrow\end{array}$ & $\begin{array}{l}\text { cortical bone fraction } \downarrow \\
\text { BV/TV and Tb.Th } \downarrow\end{array}$ & $\begin{array}{c}\text { serum OCN and RANKL } \\
\downarrow \\
\text { serum tDPD, TNF } \alpha \text { and } \\
\text { IL- } 6 \uparrow \\
\text { renal } \mathrm{Ca}^{2+} \text { reabsorption } \\
\downarrow \\
\text { urinal Ca } \mathrm{Ca}^{2+} \text { excretion } \uparrow \\
\text { renal TRPV5 and Klotho } \\
\downarrow\end{array}$ & {$[70,92]$} \\
\hline DSS & $\begin{array}{l}\text { mucosal inflammation } \\
\text { and ulceration }\end{array}$ & $\begin{array}{c}\text { BMD, Tb.Th., MAR, and } \\
\text { Ct.BMD } \downarrow \\
\text { OB.Ar } \downarrow \text { OC.Ar } \uparrow \\
\text { Growth plate height and } \\
\text { cartilage gene } \downarrow\end{array}$ & $\begin{array}{c}\text { Femoral fat pads } \uparrow \\
\text { Liver mass } \downarrow \\
\text { serum TNF } \alpha \uparrow \\
\text { IGF-1 } \downarrow\end{array}$ & [93] \\
\hline DSS & colonic length $\downarrow$ & Alveolar bone loss $\uparrow$ & Liver cystine $\downarrow$ & [94] \\
\hline DSS & $\begin{array}{l}\text { lymphocyte aggregates } \\
\uparrow ; \text { colon TNF } \alpha, \text { IFN } \gamma \text {, } \\
\text { IL- } 6 \text { and IL- } 22 \uparrow\end{array}$ & $\begin{array}{l}\text { Trabecular BV/TV, Tb.N., } \\
\text { Tb.Th. } \downarrow \\
\text { Tb.Sp. } \uparrow \\
\text { growth plate thickness and } \\
\text { ColX } \downarrow \\
\text { BFR and osteoblast surface } \\
\text { (OB.S) } \downarrow ; \text { TNF } \alpha \uparrow\end{array}$ & $\begin{array}{c}\text { inguinal fat mass } \downarrow \\
\text { retroperitoneal fat mass } \uparrow \\
\text { serum OCN } \downarrow\end{array}$ & [95] \\
\hline
\end{tabular}


Table 1. Cont.

\begin{tabular}{|c|c|c|c|}
\hline \multicolumn{4}{|c|}{ Adoptive Transfer of Effector Immune Cells to Immunodeficient Mice } \\
\hline Animal Strains & Skeletal Phenotype & $\begin{array}{l}\text { Systemic and Other } \\
\text { Organ Phenotype }\end{array}$ & Reference \\
\hline $\begin{array}{cc}\text { Severe colitis; } \\
\text { CD4+IL-10-/-Rag1-/-epithelial injury; colon } \\
\text { transfer } & \text { TNF, IFN } \gamma, \text { IL-17, } \\
\text { IL-1 } \beta \uparrow\end{array}$ & $\begin{array}{c}\text { Ct.Ar/Tt.Ar } \downarrow \\
\text { BV/TV, Conn.D, Tb.N, and } \\
\text { Tb.Th. } \downarrow\end{array}$ & $\begin{array}{l}\text { serum } \mathrm{tDPD} \text { and TNF } \alpha \uparrow \\
\text { serum RANKL } \downarrow \\
\text { renal } \mathrm{Ca}^{2+} \text { reabsorption } \\
\text { and TRPV5 } \downarrow \\
\text { urinal } \mathrm{Ca}^{2+} \text { excretion } \uparrow\end{array}$ & [92] \\
\hline $\begin{array}{cc}\mathrm{CD} 4+\mathrm{CD} 45 \mathrm{RB}-\text { scid/scid- } & \text { Colitis; immune cell } \\
\text { transfer } & \text { infiltration in colon }\end{array}$ & $\begin{array}{c}\text { Osteopenia } \\
\text { BMD and osteoblast } \\
\text { number (OB.N) } \downarrow \\
\text { TNF } \alpha \uparrow\end{array}$ & $\begin{array}{l}\text { BW } \downarrow \\
\text { SAA and WBC } \uparrow \\
\text { RBC, haemoglobin, and } \\
\text { haematocrit } \downarrow \\
\text { serum PTH, ALP } \downarrow \\
\text { TRAP } \uparrow\end{array}$ & [96] \\
\hline $\begin{array}{l}\text { CD4+CD45RB-Rag1-/- } \\
\quad \text { transfer }\end{array}$ & $\begin{array}{c}\% \mathrm{CX}_{3} \mathrm{CR} 1+\mathrm{OC} \uparrow \\
\mathrm{OC} \text { from IBD mice induce } \\
\mathrm{TNF} \alpha \text {-producing CD } 4+\mathrm{T} \\
\text { cells }\end{array}$ & BW $\downarrow$ & [97] \\
\hline \multicolumn{4}{|c|}{$\begin{array}{l}\text { Abbreviation: BFR, bone formation rate; BV/TV, Bone volume/Total volume; BMD, bone mineral density; BM, } \\
\text { bone marrow; BW, body weight; Conn.D, connective density; Ct.Ar/Tt.Ar, cortical bone fraction; MAR, mineral } \\
\text { apposition rate; Oc.S, OC surface; OB, osteoblast; OC, osteoclast; RBC, red blood cell; SAA, serum amyloid; SCFA, } \\
\text { short chain fatty acid; TJ protein, Tight junction proteins; Tb. Sp., trabecular spacing; Tb.Th., trabecular thickness; } \\
\text { tDPD, deoxypyridinoline; WBC, white blood cell; N/A, not applicable; n.s., no significant difference. } \uparrow \text { indicates } \\
\text { increase, } \downarrow \text { indicates decrease. }\end{array}$} \\
\hline
\end{tabular}

\subsection{Models Based on Genetic Modification}

\subsubsection{HLA-B27 Transgenic (B27-Tg) Rats}

Human Leukocyte Antigen (HLA)-B27 is a major histocompatibility complex class I molecule and is highly expressed on antigen-presenting cells for pathogen recognition. HLA-B27 is notably genetic associated with Ankylosing spondylitis, a class of immune-mediated arthritis termed 'spondyloarthritis' (SpA) [98]. The prevalence of HLA-B27 in SpA/IBD populations is still questionable [33], but HLA-B27 was found to be positively associated with inflammatory back disorders [99], and asymmetrical, nonerosive peripheral arthritis (namely oligoarticular) in IBD patients [100-103]. HLA-B27 transgenic (B27-Tg) rats develop a multisystemic inflammatory disease that display two important inflammatory features, IBD and peripheral arthritis resembling human spondyloarthritis [57]. B27-Tg rats are susceptible to both alveolar bone loss and long bone osteopenia with decreased biomechanical strength, increased bone resorption, increased RANKL/OPG mRNA ratio in bone tissue [58], and enhanced osteoclastogenesis [59]. However, this model displayed normal serum level of bone formation markers, such as OCN [60] and PINP [58], which indicates that inflammation-associated bone loss in B27-Tg rats is mainly driven by increased bone resorption. Previous studies revealed HLA-B27-associated gut and joint inflammation is prevented when transgenic rats were in a germ-free environment [104]. Recent studies from Ansalone et al. [61] demonstrated that B27-Tg rats have enhanced number of bone erosive circulating monocytes, which are highly dependent upon microbiota-regulated intestinal inflammation. These findings highlight the participation of intestinal microbiome in the pathologic relation between HLA-B27-associated gut, bone loss, and joint inflammation.

\subsection{2. $V D R-/-$ Mice}

$V D R$ null mice were generated to understand the role of Vitamin D3 in the gut-bone axis. In addition to bone and intestine, VDR is widely expressed in many other tissues including endocrine tissues, skin, kidney, bone marrow, and lymphoid tissues. $1,25(\mathrm{OH})_{2} \mathrm{D}_{3}$ and VDR, and together with other active co-regulatory proteins results in maintenance of calcium homeostasis by increasing calcium absorption from the intestine and preventing bone resorption. Deficiency of VDR in mice 
caused rickets, osteomalacia, hypocalcemia, and hyperparathyroidism, and those symptoms were prevented when a high calcium (2\%) containing diet were fed in VDR null mice, which indicates that VDR deficiency induced skeletal disorder are principally as a result of failed intestinal calcium absorption [62,63]. Further studies from Xue et al. [64], using transgenic expression of VDR in the intestine of VDR-knockout mice, showed that calcium homeostasis was directly restored, and that intestinal VDR is essential for controlling bone formation. IEC-specific VDR knockout $(\operatorname{Vdr}(\triangle I E p C))$ mice exhibit abnormal body size and colon structure [66], and significantly-reduced skeletal calcium levels that maintain normal levels of ionized calcium in serum. Additionally, increased compensatory $1,25(\mathrm{OH})_{2} \mathrm{D}_{3}$ levels in $V d r(\Delta I E p C)$ mice did not rescue increased bone turnover and suppressed bone matrix mineralization, leading to osteopenia [67]. Most recent studies on the roles of VDR expressed in bone cells revealed that VDR in OBs, but not in OCs, negatively regulate bone mass, since ablation of VDR in OBs results in reduced bone resorption with a decreased expression of RANKL in OBs [105,106]. Although the role of VDR and vitamin D on the progression of IBD is unclear, VDR and vitamin D may be important for proper bone remodeling and formation of high quality bone in the setting of disease.

\subsubsection{IL-10 Deficiency}

IL-10 is a well-known anti-inflammatory cytokine, and decreased IL-10 levels contribute to pathological development in both IBD and inflammatory bone disease. In the study from Drezner-Pollak et al., IL-10-/- mice spontaneously develop colitis and exhibit decreased bone mass due to decreased bone formation, without affecting bone resorption [68]. The primary defect in bone formation in IL-10-/- mice was evidenced by decreased bone formation rate, serum OCN level, and mineralized nodule number in bone marrow stromal cell cultures. A following study from Ciucci et al. compared bone from $I L-10-/-$ mice with colitis to $I L-10-/-$ mice without colitis by histomorphometry [69]. IL-10-/- mice with colitis developed a significant bone defect with reduced trabecular thickness, trabecular number, and bone surface density [69]. Those findings show that osteopenia and OP found in IL-10-/- mice is primarily due to colitis-associated intestinal inflammation, but not IL-10 deficiency. However, it has been shown that IL-10 itself inhibits bone resorption by decreasing osteoclastogenesis $[107,108]$. Additional work is required to reconcile these mechanistic differences.

\subsubsection{IL-2 Deficiency}

IL-2, a cytokine predominantly secreted by activated T cells, is critical for the development and peripheral expansion of $\mathrm{CD} 4+\mathrm{CD} 25+$ regulatory $\mathrm{T}$ cells, promoting self-tolerance by suppressing $\mathrm{T}$ cell responses in vivo $[109,110]$. IL-2-/- mice spontaneously develop a systemic autoimmune inflammation characterized by colitis, hepatitis, pneumonia, hemolytic anemia, and osteopenia [71,72]. Ashcroft et al. showed that $I L-2$ deficient mice developed colitis and pronounced osteopenia with reduced bone formation and increased OC number, caused by elevated level of RANKL in both serum and bone marrow mononuclear cells. IL-2 deficient mice display heavily inflamed large bowel with significantly higher systemic RANKL level at 7 weeks. The abundance of RANKL may also benefit survival and activity of intestinal dendritic cells by activating pathogenic $\mathrm{T}$ cells $[72,111]$. Transfer of CD3+ T cells from IL-2-/- mice into lymphocyte-deficient C57BL/6-Rag1-/- mice, resulted in lower femoral BMD, trabecular volume, and significantly higher number of OCs. This work suggests activated T cells, due to $I L-2$ deficiency, may contribute to induction of bone loss in the setting of colitis by inducing OC formation. It emphasizes the importance of IL-2 as a therapeutic target for bone defects associated with intestinal inflammation.

\subsubsection{Tnf $\triangle A R E$ Mice}

Tumor necrosis factor (TNF) is a main factor linking the pathology of gut-bone axis. This was demonstrated by TNF transgenic mouse model (Tnf $\triangle A R E$ mice), generated by deleting TNF AU-rich elements (ARE) responsible for destabilizing activity on the TNF message. These mice spontaneously develop chronic inflammatory polyarthritis at weeks 5-6 and Crohn's-like IBD at week 6 [73]. Moreover, 
these mice showed enhanced circulating TNF levels and profound capacity of macrophages and T cells to produce TNF. This model is effective for studying severe systemic inflammatory diseases as seen in clinical human patients, since most patients have systemic inflammation that is not isolated to a single organ system. However, the systemic nature of this model makes it difficult to understand the specific effect of gut inflammation on other regions of the body.

3.1.6. $g p 130^{\triangle S T A T / \Delta S T A T}$ and $g p 130^{Y 757 F / Y 757 F}$ Mice

The proinflammatory cytokine IL- 6 and its receptor gp130 are essential for the pathogenic development of both intestinal and bone disease, such as RA. Genetic manipulation of the IL-6/leukemia inhibitory factor (LIF) cytokine axis through sustained activation of gp130 in mice ( $g p 130-K I$ mice/gp130 $\triangle S T A T / \triangle S T A T)$, causes severe joint disease with features representative of RA, and interestingly, GI ulceration [74]. Those mice showed a severe chronic synovitis, degraded articular cartilage associated with disrupted chondrocyte differentiation, but normal trabecular bone volume (BV/TV) and turnover [75]. $g p 130^{\triangle S T A T / \triangle S T A T}$ mice display sustained gp130-dependent signal transducer and activator of transcription (STAT) signaling cascades due to impaired STAT-mediated induction of suppressor of cytokine signaling-1 (SOCS-1), which normally functions to limit gp130 signaling [112]. Dysregulation of STAT1 and/or STAT3 activity is associated with human hematological and intestinal disease [113], such as gastric cancer [114]. Unlike gp130 ${ }^{\triangle S T A T / \triangle S T A T}$ mice, BV/TV was reduced in gp130 receptor mutant mice ( $\left.g p 130^{Y 757 F / Y 757 F}\right)$ due to highly activated bone turnover [75]. The work from this model, combined with evidence that IL-6 levels are elevated in IBD patients, suggests a role for gut-induced IL-6 expression as a mediator of bone quality.

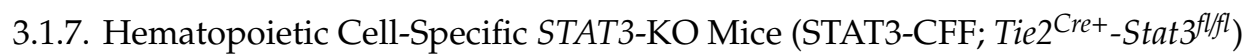

Signal transducer and activator of transcription 3 (STAT3) is a transcriptional mediator responsible for the expression of many inflammatory cytokines, including IL-6, IL-10, and G-CSF [115], exerting its role in a cell-specific way [116]. Mice with hematopoietic cell-specific disruption of STAT3 gene (STAT3-CFF) generate an osteoporotic phenotype with hyperproliferated myeloid lineages and increased number of OC precursors, indicating existence of higher osteoclastogenic factors in those mutant mice [117]. Another study from Welte et al. showed STAT3-CFF mice displayed a CD-like pathogenesis in both the small and large intestine, characterized with segmental inflammatory cell infiltration, ulceration, and formation of granuloma [76]. An alternative study also documented that STAT3-CFF mice have defective stem/progenitor cells with mitochondrial dysfunction, increased reactive oxygen species (ROS) production, and a rapid aging-phenotype [77]. All these findings suggest that STAT3 signaling pathway and its associated factors, such as ROS and mitochondrial function, contribute to both inflammatory bowel and bone diseases. Work remains to be done on connecting the two organs in this model and understanding how bowel-specific STAT3 signaling may affect bone remodeling.

\subsubsection{A20 (Tumor Necrosis Factor $\alpha$-Induced Protein3; TNFAIP3) Deficiency}

Nuclear factor- $\mathrm{kB}$, a key nuclear transcriptional factor, is a central player in regulating expression of a variety of genes encoding proinflammatory cytokines, adhesion molecules, chemokines, growth factors, and inducible enzymes $[118,119]$. NF- $\mathrm{KB}$ itself is activated by many different stimuli ranging from inflammatory cytokines to genotoxic stress. Pathogenesis in both IBD and inflammatory bone disease is characterized by elevated inflammatory cytokines, many of which are regulated through activation of NF- $\mathrm{KB}$ signaling. Dysregulation of NF-KB inhibitory pathways in mice can cause severe systemic inflammation. One such model is characterized by reduced $A 20$ (tumor necrosis factor $\alpha$-induced protein3; TNFAIP3) expression (A20-KO mice), which normally regulates NF- $\mathrm{kB}$ activation. A20 deletion triggers severe inflammatory conditions in multiple organs, including livers, kidney, intestines, joints, and bone marrow, and dies prematurely [120]. Studies on cell-specific A20 function, by using conditional knockout mice, showed that A20 deficiency in myeloid cells $\left(A 20^{\text {myel }}-K O\right)$ 
results in spontaneous development of severe destructive polyarthritis resembling RA [78]. Although intestinal epithelial cell (IEC) specific A20 knockout mice, and $A 20^{\text {myel }}$-KO mice showed preserved intestinal integrity, models combining IEC and myeloid A20 deletion display ileitis and severe colitis, characterized by elevated inflammatory cytokine pool [79]. This work suggests that both an extracellular source of inflammatory stimulation, combined with defective intestine-specific intracellular signaling, may be required for the development of gut disease.

\subsubsection{IKK2 $\mathrm{ca}^{\mathrm{IEC}}$ Mice}

To further interrogate the role of NF-kB signaling in the gut-bone axis, our lab generated an IEC-specific model of NF- $\mathrm{KB}$ overactivation. The findings from our studies using IEC-specific constitutively activated IKK2 mice (IKK2 $\mathrm{ca}^{\mathrm{IEC}}$ ) model highlight direct and crucial role of intestinal NF-KB signaling in linking chronic gut inflammation with bone loss [80]. IKK2ca ${ }^{\mathrm{IEC}}$ develop a mild inflammation in small intestine [81]; however, with significantly elevated serum and epithelial level of inflammatory cytokines. Importantly, IKK2 $\mathrm{ca}^{\mathrm{IEC}}$ mice recapitulate the majority of the phenotypes observed in chemically (Dextran sulfate sodium/DSS) induced colitis, such as altered gut-residing cells and elevated osteoclastogenic cytokines. Furthermore, moderate attenuation of NF- $\mathrm{KB}$ signaling by using conditional deletion of one allele of IKK2 in IECs or pharmacological inhibition of IKK2, partially attenuated circulating levels of inflammatory cytokines, such as IL-17, and halted colitis-associated bone loss. This indicates that NF- $\mathrm{KB}$ signaling in intestinal cells is not only critical for gut inflammation-mediated damage, but also extra-intestinal effects.

\subsubsection{FXR-/- Mice}

The farnesoid $X$ receptor (FXR), a nuclear receptor for bile acids, is highly expressed in intestine and liver and responsible for maintaining bile acid homeostasis. FXR displays various functions in different organs, and the FXR antagonists have been developed for pre-clinical and clinical application for management of liver and other metabolic disease [121]. FXR-/- mice display compromised intestinal epithelial barrier due to increased bacterial invasion [122], increased colon cell proliferation and apoptotic goblet cells, accompanied with upregulation of genes involved in cell cycle progression and inflammation, such as cyclin D1 and IL-6 [83]. The changes in the intestinal microbiota during metabolic dysfunction, such as obesity and alcoholic liver disease, have been shown to be associated with FXR $[123,124]$. FXR deficiency leads to cell proliferation, inflammation, and tumorigenesis in gut, and FXR can protect small intestine from bacterial invasion and colonization [125]. Cho et al. demonstrated that $F X R-/-$ mice display reduced bone formation rate as well as low trabecular bone volume and reduced thickness [84]. Evaluation of FXR effect on bone cell differentiation showed that mice with FXR deficiency had reduced OB differentiation [84], and enhanced OC generation [85]. Zheng et al. [85] assessed role of FXR in different pathological bone loss models (calvarial injection of LPS, in vivo rosiglitazone treatment, ovariectomy (OVX) surgery, and unloading-induced bone loss), and reported that deficiency of FXR accelerated bone loss in animal model of postmenopausal $\mathrm{OP}$ and unloading-induced bone loss. Taken together, these findings strengthen both biological and pathological function of FXR in bone loss and highlight a possible role of FXR in connecting intestinal inflammation and its-related bone disease when FXR is downregulated. Further work has to be performed to determine how intestinal inflammation may modulate FXR ligands to signal to the skeletal system through cell specific deletion models.

\subsubsection{Mdr2-/- Mice}

Multi-drug resistance 2 (encoded by $m d r 2 / A b c b 4$ ), known as a canalicular phospholipid flippase, is responsible for transport of phospholipid into bile by increasing efflux of intracellular hydrophobic drugs observed in multidrug resistance (MDR) $[126,127]$. The $m d r 2-/-$ mouse spontaneously develops severe biliary fibrosis due to an accumulation of toxic bile acids, and is considered as a model of primary sclerosing cholangitis (PSC) [128]. PSC is a cholestatic liver disease characterized by chronic 
inflammation and progressive destruction of the bile ducts. PSC displays remarkable associations with IBD, dysbiosis and higher incidence of fracture risk [129,130]. Mdr2-/- mice display an altered GM, intestinal barrier dysfunction, and activation of NLRP3 inflammasome within the gut-liver axis. Interestingly, healthy control mice transferred with $M d r 2-/-$ microbiota develop significant liver injury, highlighting the key function of intestinal dysbiosis in the progression of liver disease [86]. Schmidt et al. demonstrated decreased bone mass in PSC patients is associated with increased bone resorption, as well as increased peripheral blood T helper (Th)17 cells. Experimental studies showed that $M d r 2-/-$ mice had a higher Th17 cell frequency in liver. Analysis of skeletal phenotype displayed that absence of Mdr2 in mice resulted in osteopenia with reduced trabecular bone mass, and this phenotype was prevented by the additional Il17af deficiency [87]. An increased Th17 response to microbial stimulation was found in PMC patients with UC [131]. These findings point out that mdr2-regulated dysbiosis may contribute to two major complications found in PSC patients: IBD and bone loss, potentially through modulation of immune cell populations.

\subsection{Models Based on Dysbiosis-Associated Gut Inflammation}

The gut is an especially unique organ system due to the present of its vast microbiome that is critical for healthy function but also pathophysiology. Dysbiosis is highly associated with GI disease, characterized by imbalanced microbiota population as well as microbial metabolism. Therefore, recent work using animal models to manipulate host microbiota offer a method to understand the role of the microbiome in gut-related disease and associated bone loss. Animal studies to explore dysbiosis-regulated bone loss were mainly performed by using germ-free (GF) animals and antibiotic treatment [132].

\subsubsection{Germ-Free (GF) Models}

GF models are established by raising animals in sterile conditions, which result in a lack of microbiota in those animals and an immature mucosal immune system [133]. This allows for colonization with specific microbiota to determine the effect of individual bacterial species on physiology. GF animals display enlarged ceca, reduced total mass of intestine and total surface of small intestine, shorter crypts of small intestine, and decreased cellularity in lamina propria, compared to conventionally raised animals (CONV-R) [134]. GF mice displayed increased trabecular bone mass due to compromised osteoclastogenesis, compared with CONV-R mice. Colonization of young GF mice (3 weeks old) with normal GM (for 4 weeks) normalized bone mass to a level similar to CONV-R mice [88]. Subsequent study from Yan et al. showed long-term colonization of 2 month old GF mice with conventional specific pathogen-free GM for 8 months results in equalization of bone mass between GF and conventional groups. Long term conventionalization of GF mice also increased longitudinal and radial bone growth, although an acutely reduced bone mass was found when a short-term (1 months) colonization was conducted [90]. Colonized GF mice also showed an increased circulating level of insulin-like growth factor 1 (IGF-1), a hormone known to effectively regulate skeletal growth. Together, these observations suggest a complex relationship between GM and bone remodeling over the lifetime of the animal. Hence, the role of GM and their impact on the skeletal system requires further work developing clinically-relevant strict GF animal quality control procedures to tease apart these effects.

\subsubsection{Antibiotics Treatment Models}

An alternate method to study GM is by using antibiotic treatment to kill specific subsets of bacteria. This method has the benefit of being highly translational in order to study the impact of antibiotics in humans as well. Treatment with broad-spectrum antibiotics commonly reduce or deplete microbiome population in gut, with increased size of cecum, decreased proliferative cells in small intestine and colon, but with fewer effect on overall colon length [132]. Yan et al. showed antibiotic treatment of CONV-R mice decreases serum IGF-1 level and inhibits bone formation [90]. However, supplemental treatment with short-chain fatty acid (SCFAs), one of the products of microbiota metabolism, restored 
serum IGF-1 and bone mass level in antibiotic-treated CONV-R mice [90], suggesting that metabolic products of bacteria can regulate the host skeleton. The other alternative study showed a mild range of antibiotic treatment at early life significantly increase BMD in CONV-R mice [135], as well as serum glucose-dependent insulinotropic polypeptide (GIP), an incretin hormone promoting bone formation [136]. Those results are consistent with the finding that daily injection of GIP could rescue bone loss found in OVX animal model [137]. Importantly, multiple studies provide evidence that supplementation of probiotics (i.e., Lactobacillus reuteri, Lactobacillus rhamnosus GG (LGG), Lactobacillus paracasei and/or Lactobacillus plantarum) in OVX mice can limit bone loss by dampening osteoclastogenic cytokine production in bone marrow and/or intestine due to ovary malfunction [138-140]. Based on experimental data, intestinal microbiota display a great potency to regulate bone metabolism via regulating host metabolism, immune response, and endocrine factors. Normalization of the intestinal microbiota directly or indirectly, for example, dietary interventions by using pro-and/or synbiotics, may be provided for pre-clinical application for treating metabolic disease and GI disorder-associated bone disease.

\subsection{Chemical Irritant-Induced Model}

The use of chemical irritants to induce IBD in mice has been one of the most highly utilized, non-genetic models for studying the impact of IBD systemically. Several such models have been developed, and although they do not mimic the direct pathophysiology of human IBD, they display similar phenotypic changes as human patients [141].

\subsubsection{Trinitrobenzene Sulfonic Acid (TNBS)}

Colitis induced by trinitrobenzene sulfonic acid (TNBS), a classical haptenating agent, is mainly conducted through intrarectal administration to trigger production of immunogenic proteins in the colon, thereby initiating a mucosal immune response such as increased cytokine production [142]. An early report by using TNBS-administration in rats showed that significant cancellous bone loss $(33 \%)$ could be observed 3 weeks after treatment, due to reduced cancellous bone formation rate ( $<30 \%$ versus control). Following the resolution of the inflammatory process, TNBS-treated animals exhibit increased bone formation by 12 weeks into the experiments [143], indicating the potential for rescue after disease resolution. A recent study by Metzger et al. reported systemic inflammation developed in TNBS-induced IBD elevates proinflammatory cytokines levels (TNF- $\alpha$, IL-6, RANKL) and decreases sclerostin, a known bone formation inhibitor, in osteocytes [91]. These findings highlight potential contribution of bone formation modulating cells, OB, and osteocytes, in bone loss associated with TNBS-induced IBD. Other studies demonstrated increased TNF and interferon-gamma (IFN $\gamma$ ) in TNBS-treated mice can downregulate expression and activity of Klotho, an anti-inflammatory protein by supporting renal $\mathrm{Ca}^{2+}$ homoeostasis $[70,92]$.

\subsubsection{Dextran Sulfate Sodium (DSS)}

An alternate chemically induced IBD model is the well-established DSS colitis model. This model utilizes DSS to induce dysfunction of intestinal epithelial barrier, thereby resulting in exaggerated entry of luminal bacteria or antigen into mucosa [144,145]. The effect of DSS on the induction of bone loss is dependent upon DSS dosage, treatment periods, and animal background (age, sex, and species). Low dose treatment of DSS (1\%) in 5-6 weeks old male mice for 15 days induced a moderate intestinal inflammation without weight loss [95]. Those mice displayed significant trabecular bone loss with increased TNF- $\alpha$ in bone and colon, which is negatively correlated with OB activity, leading to decreased bone formation rate, but few effects on cortical bone. Interestingly, low dose DSS treatment induces a redistribution of fat storage from subcutaneous to visceral sites, which is reported to be more proinflammatory and consistent with disease pathologies (e.g., Creeping fat accumulation) found in CD patients [146-148]. Studies from Harris et al. reported a transition in bone composition occurred following active IBD phases [93]. During active disease phase, DSS-treated mice showed 
a significant decrease in tibial trabecular and cortical bone parameters, lower vertebral trabecular bone parameters, but few effects on calvaria BMD. Active inflammation in intestine is associated with dramatically increased serum level of TNF- $\alpha$ and reduced IGF-1, associated with decreased bone length, growth plate thickness, and cartilage markers. However, both OC and OB activity declined during active disease stage, indicating decreased overall bone remodeling. During disease recovery, DSS-treated mice recovered body weight and skeletal response. Different from previous groups, Hamdani et al. [149] used Balb/C mice to investigate DSS colitis-induced bone loss, and they found reduced femoral bone mass resulting from suppressed bone formation and increased bone resorption in the DSS-colitis model. Interestingly, endogenous bone marrow mesenchymal stem cells (BMMSCs) have an immunosuppressive capacity, maintained by autophagy, that can improve the intestinal pathologic index in DSS-colitis mice, highlighting reciprocal interaction between the gut and bone [150]. However, BMMSCs from OVX mice lost this immunoregulatory capacity, exhibited decreased osteogenic differentiation and increased adipogenic differentiation. The restoration of autophagy by rapamycin rescued BMMSCs' healing capacity and attenuated the OP phenotype in OVX mice. These different findings indicate the despite its simplicity and wide application, DSS-induced colitis is complicated by various factors, which make it challenging to study the impact of colitis on bone. However, this can also provide insight into the various modes and severity of intestinal inflammation-associated bone loss observed in human patients.

\subsection{Immune Cell-Transfer Induced Model (CD45RB Model)}

A prominent feature of chronic gut inflammation in IBD is the presence of activated inflammatory $\mathrm{T}$ cells as well as their secreted cytokines. Differentiation/expansion of donor (Wild-type)-derived naïve $\left(\mathrm{CD} 4+\mathrm{CD} 45 \mathrm{RB}^{\mathrm{Hi}}\right) \mathrm{T}$ cells in immune-deficient recipient (Rag-/-; scid/scid mice) induces transmural colitis with severe inflammation within small bowel [151]. Experimental data showed that, in addition to colitis, scid/scid mice transferred with CD4+CD45RB ${ }^{\mathrm{Hi}} \mathrm{T}$ cells (CD45RB mice) developed osteopenia characterized with decreased total (trabecular and cortical) BMD, increased OC number in long bone surface and decreased number of OBs [96]. CD45RB mice also displayed bone marrow inflammatory cells expressing higher TNF- $\alpha$. Prophylactic treatment with Fc-OPG, a soluble decoy receptor binding and neutralizing RANKL, increased bone density in CD45RB mice by preventing OC function, normalizing serum $\mathrm{Ca}^{2+}$ and Pi concentration, but failed to recover gut inflammation. A similar therapeutic function of OPG in gut-inflammation associated bone loss was also found in IL-2-/colitis mice, in which both skeletal abnormalities and colitis score were reduced by modulation of RANKL-RANK interactions with exogenous administration of Fc-OPG [72]. The potential critical effect of systemic and intestinal RANKL in bone loss and osteoclastogenesis is also revealed in our recent study [80]. To sum up, the role of the RANK/RANKL signaling pathway in location inflammation is still needed to be addressed in different gut inflammation models.

\section{Networks of Gut-Residing Factors Regulating Bone Marrow Microenvironment and Bone Loss}

The intestine and bone marrow are two representative central reservoirs of immune cells. Inflamed gut environment, driven by unrestrained immune-cell activation, increased pro-inflammatory cytokine production, associated with altered resident microbiotas and dysfunction of epithelial barrier, results in increased inflammation in bone marrow microenvironments and subsequently decreased bone mass (Figure 1). 


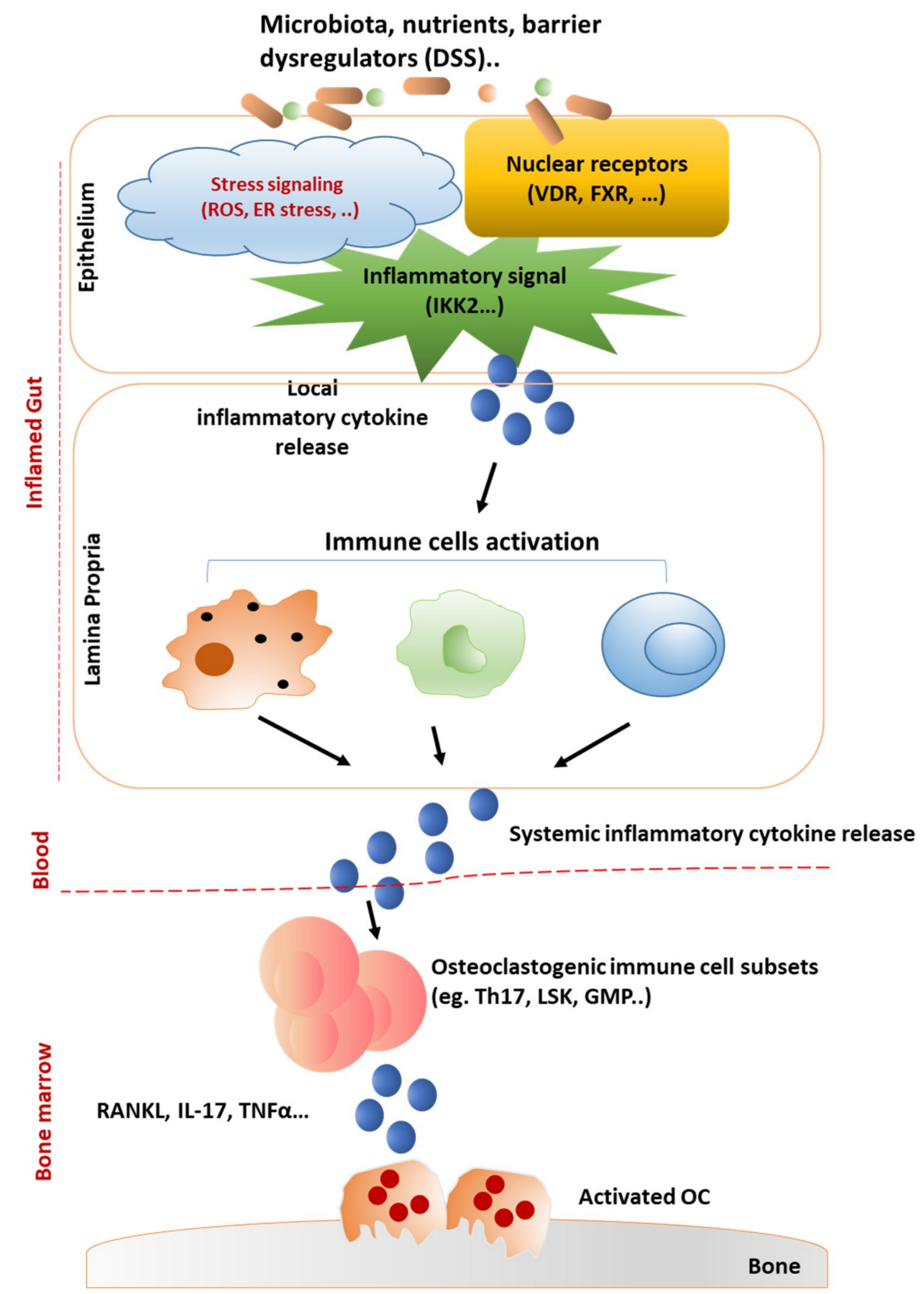

Figure 1. Networks of gut-immune response in bone loss. Many factors, including microbiota and/or barrier-damaging factors (e.g., DSS), have been validated in triggering gut inflammation, such as IBD. In inflamed gut, epithelial barrier function can be regulated by nuclear receptros (VDR, FXR), inflammatory signals (NF- $\mathrm{B}$ ), and various stress stimulators (ROS, Endoplasmic Reticulum (ER) stress). Various inflammatory responses can be activated in the lamina propria by the infiltrating bacteria and/or local released inflammatory cytokines from epithelium cells. Dysregulation of the balance between mucosal immune cells orchestrate cytokines production and releasing to blood stream. Systemically provided inflammatory cytokines could be transmitted to bone marrow to enable activation of osteoclastogenic immune cells and cytokines, leading to activated bone resorption process by osteoclasts (OC). 


\subsection{Intestinal Barrier-Regulated Bone Loss}

Intestinal epithelial barrier, an integral component of innate immunity, provides a shield against microorganisms harbored in lumen. The intestinal barrier is mainly composed of a single layer of various cell types (i.e., IEC, enterocytes, goblet cells, neuroendocrine cells, tuft cells, Paneth cells, and $\mathrm{M}$ cells), which respond to various extracellular stimuli and provide priming and activation signals to a diversity of immune cells residing in the lamina propria to promote an effective inflammatory response [152,153]. The intestinal epithelial cells make up the majority of the luminal surface where they are connected by tight junctions (TJ), which are responsible for connecting adjacent epithelial cells and are critical for controlling interepithelial permeability and selectively controlling passage of small molecules. Studies in active CD patients showed increased intestinal paracellular permeability which is associated with altered TJ protein complex, such as suppressed expression of transmembrane protein occludins, and claudins 5 and 8, but upregulated claudin-2, a mediator of leaky gut barrier [154]. These emphasize the key role of TJ protein in shaping epithelial structure, restraining pathogen passage, and maintaining gut barrier function.

Current knowledge of the crosstalk between intestine and bone during gut inflammation is based off both clinical and animal models [155]. Pediatric IBD patients showed an increased likelihood to develop OP or osteopenia due to impaired barrier function. Early studies showed that premature birth can increase intestinal permeability and, surprisingly, bone mineral content [156]. Another study found that infants with low birth weight were more likely to develop bone metabolic disease [157]. The effects of intestinal health during early development can clearly have long-term effects on bone health, especially since younger children undergo higher rates of bone remodeling. This could also be potentially associated with high permeability of intestinal barrier during early phase of development. Breastfeeding may allow passage of multiple components, including lactoferrin, transforming growth factor beta (TGF $\beta$ ), and epidermal growth factor (EGF) from the mother's colostrum to the infants' blood. Those components improve infants' intestinal permeability by promoting TJ protein expression [158], as well as provide easily digestible nutrition for infants. In addition, IgA antibodies found in breast milk have been shown to improve gut microbiota and overall intestinal health, reducing the risk of IBD. Although more evidence is needed to prove an association between bone loss and intestinal barrier dysfunction, studies on animal models using chemically-induced barrier permeability [93,149] and by targeting epithelial function through genetic modification [80], support this notion. A major drawback of this clinical finding is small sample sizes and highly specific patient populations that may not represent broad patient groups. Typically, proinflammatory cytokines TNF $\alpha$ and IL-1 $\beta$, which are increased in IBD patients, have been shown to directly increase IEC permeability by interrupting TJ proteins, associated with increased activation of NF- $\mathrm{KB}$ signaling, the primary inflammatory response pathway [159-162]. Those results are consistent with our findings in IKK2ca IEC mice, wherein constitutive activation of NF-kB signaling pathway in IECs [80], which mimics chronic inflammation, can induce gut damage and directly affect bone regulating cells (such as OC precursors) via gut-secreted cytokines.

A recent update shows that intestinal epithelial barrier can respond to endoplasmic reticulum (ER) stress under inflammatory conditions, and Genome-wide association studies, (GWAS) based on a large cohorts of IBD patients undercovering over 300 susceptibility genes, revealed a high correlation between endoplasmic reticulum stress as well as unfolded proteins (UPR)-related genes and the pathogenesis of IBD $[163,164]$. Reports on animal studies showed that mice with epithelial-specific deletion of X-box-binding protein (XBP1) spontaneously developed enteritis, exhibited a higher susceptibility to induce colitis due to dysfunction of Paneth cells and high sensitivity to bacterial products (flagellin) and $\mathrm{TNF} \alpha$ [165]. Another recent study emphasizing the importance of ER protein in epithelial function displayed mice with epithelial specific disruption of Inositol Requiring Enzyme1 $\alpha$, an ER transmembrane protein serving as the major sensor under stress, spontaneously developed colitis with a loss of goblet cells and failure of intestinal epithelial barrier function [166]. The importance of ER stress signaling is not only reflected by its role in maintaining physiology, 
but also by its high response to genetic mutations, oxidative stress, process of aging, and/or various environmental factors that can lead to different diseases such as obesity, inflammation, diabetes, GI disorders, and rheumatic disease (RA) [167-169]. In spite of the lack of evidence proving direct link between ER stress presented in IBD and bone disease, the promising effect of UPR in bone cells differentiation and functions has been investigated in multiple studies. Scheiber et al. showed that G610C osteogenesis imperfecta mice had longitudinal bone growth retardation, characterized by accumulated hypertrophic chondrocytes expressing ER dilation, and mutated type I collagen which induce osteoblast dysfunction due to ER stress [170]. ER stress also reflects one of the promising therapeutic mechanisms during rheumatoid disease process. For example, induction of UPR signaling by inflammatory cytokines and autoantibodies can act as upstream pathway to induce inflammatory responses during RA pathogenesis [169]. Upregulated expression of representative ER stress markers, including GRP78, IRE1, XBP1s, ATF6, and eIF2 $\alpha$-P, were found in macrophages and synovial tissues from RA patients [171,172]. Tauroursodeoxycholic acid (TUDCA), an endogenous chemical chaperone that protects cells against ER stress, has been shown to attenuate intestinal inflammation and barrier disruption in various disease models, such as DSS-induced colitis $[173,174]$ and non-alcoholic fatty liver disease [175]. The effect of TUDCA in bone was also investigated in experimental models which displayed that TUDCA was comparable to recombinant human bone morphogenetic protein-2 possessing osteogenic potential in a mouse spinal injury model [176], and an alternative treatment to restore OA cartilage by balancing intracellular cholesterol levels in chondrocytes [177]. Therefore, targeting dysregulated UPR signaling in gut and/or bone marrow microenvironment may be proposed as new therapeutic strategy for IBD-associated bone destruction.

Another recent potential theory that links intestinal barrier dysfunction and skeletal failure presented in IBD could be autophagy, a conserved catabolic process by which cells control degrading damaged protein, dysfunctional organelles and clearance of bacteria [178]. Activation of autophagy machinery has been indicated in various human diseases [179]. GWAS analysis identified autophagy protein (ATG16L1) as an IBD susceptibility gene [180], representing key roles in both human and mouse intestinal Paneth cells [181]. Adolph et al. reported that mice with epithelial specific compromised UPR (XBP1) and autophagy function (ATG16L1) spontaneously developed severe CD-like transmural ileitis [182], accompanied with NF- $\kappa B$ overactivation-mediated intestinal inflammation. Several studies revealed regulation of autophagy on bone cell development and function, as well as the effects of autophagy on bone microenvironment are context-dependent [183-187]. Wu et al. reported that IEC-specific VDR regulated ATG16L1 level at both transcriptional and translational level [188]. Additionally, the negative correlation of intestinal VDR expression and ATG16L1 is found in UC patients as well as IL-10-/- mice with colitis. Bone marrow-derived macrophages from IL-10-/- mice displayed an impaired induction of autophagic pathway upon LPS stimulation [189], implicating selective local activation of autophagy, i.e., in gut or bone, may explain osteopenia shown in IL-10-/mice [68]. Qi et al. presented that autophagy maintains the immunoregulatory capacities of BMMSCs in modulating T cells apoptosis, gut inflammation in DSS-colitis mice, but BMMSCs from OVX/OP models failed to exert regeneration capacity [150]. Clinical data also showed promising therapeutic effect of mesenchymal stem cells for the treatment of UC [190]. Overall, these findings indicate that modulation of novel signaling pathways, such as NF- $\mathrm{kB}$, UPR, and autophagy, can regulate cytokine production in the inflamed gut environment to limit bone destruction.

\subsection{Effect of Gut-Derived Cytokines on Bone Marrow Microenvironment}

Patients with IBD display elevated levels of circulating pro-inflammatory cytokines with osteoclastogenic function, such as TNF $\alpha$, IL-1 $\beta$, IL-6, IL-11, IL-17, and prostaglandin E2 [7]. These osteoclastogenic factors presumably act on OC precursors residing in bone microenvironment to promote OC differentiation and bone resorbing capacity. Additionally, some of those cytokines disrupt bone formation by inhibiting $\mathrm{OB}$ differentiation and bone formation. Thus, the dual effects of these inflammatory cytokines lead to a substantial bone erosion effect and further result in skeletal 
anomaly. Neutralization of pro-inflammatory cytokines, such as TNF $\alpha$ and IL-6, which are increased in the circulation of active IBD patients, can therapeutically recover IBD-associated bone loss [191], highlighting the important role of effector cytokines in the effects of IBD on bone remodeling. In murine studies, varying contributions of cytokines in IBD-associated bone defects have been reported.

At the onset of IBD, dysfunction of epithelial barrier with higher permeability cause accumulation of GM and increased innate immune cells response, excessive influx and activation of lymphocytes including neutrophils, macrophages, dendritic cells, and innate lymphoid cells (ILC) [192]. These cells produce high quantities of pro-inflammatory cytokines (IL-1 $\beta$ and TNF $\alpha$ ), which are more actively produced at the onset of gut inflammation $[193,194]$. Our most recent studies showed both IEC and ILCs, the representative innate immunity regulating components, are responsible for initiation of murine osteopenia due to intestinal barrier dysfunction [80]. Furthermore, since IBD is characterized by recurrent chronic inflammation, the adaptive immune response plays a key role in the development of IBD-associated bone loss [195]. Gut inflammation has been characterized by overactivated pro-inflammatory cytokine-producing T-helper cells, such as Th1 and Th17, in addition to ineffective anti-inflammatory regulatory $\mathrm{T}$ cells to resolve the inflammation [195]. Unrestrained gut-immunity in IBD is associated with divergent responses in lymphoid and myeloid hematopoiesis in the bone marrow. Trottier et al. and others showed that colitis in mice induces significant increase of neutrophils, monocytes, and granulocytic lineage, but a decline of lymphocyte population (B and $\mathrm{T}$ cell lineage) in bone marrow and peripheral blood, which is consistent with the highly infiltrated monocytes and neutrophils in intestine [196,197]. However, the key drivers of inflammation in the IBD-derived bone marrow still remain to be addressed. Ciucci et al. identified in two characterized mouse models of IBD (IL-10-/- and CD45RB model), as well as CD patients, that bone marrow-Th17 cells expressed higher levels of osteoclatogenic cytokines, including IL-17 and TNF $\alpha$ upon gut inflammation [69]. These findings are consistent with previous observations that intestinal inflammation in IL-2-/- mice is associated with activated $\mathrm{T}$ cells accumulation in the bone marrow and highly produced RANKL [72]. Oostlander et al. also suggested an important role of IL-17 in OC differentiation in CD patients [198]. Attenuation of NF- $\mathrm{KB}$ signaling during gut inflammation in mice limit bone loss by modulating circulating IL-17 level [80], highlighting the key function of IL-17 in gut-bone inflammation.

To date, direct evidence supporting the effect of gut-residing cells as well as their secreted cytokines on bone remodeling still needs further exploration. However, gut microbial dysbiosis may be the key driver to aberrant immune response, often accompanied with imbalanced production of inflammatory cytokines. Data of the Human Functional Genomics Project, derived from in vitro stimulation experiments, demonstrate that TNF $\alpha$ and IFN $\gamma$ production are more directly influenced by the GM [199], suggesting the possibility of modulating the host immune response by manipulating microbiota-mediated factors, i.e., cytokines, rather than direct targeting of the immune cells. Mice in GF condition exhibit increased bone mass and compromised marrow CD4+ T cells and osteoclastogenic cytokines, which can be normalized by conventionalization [88,89,139,200]. Shaping of GM in B27-tg rats modulates onset of gut and joint inflammation [104]. Several experimental studies also emphasize the critical role of microbial dysbiosis in linking metabolic dysfunction-associated gut inflammation and bone loss [201]. For example, mice with ovary dysfunction display an increased intestinal permeability [139,202] with altered intestinal TJ and cytokine gene expression [202]. Probiotics supplementation improves bone loss and intestinal permeability following OVX [138-140]. GF mice are protected from bone loss and barrier dysfunction due to sex-steroid deprivation, by dampening bone marrow and gut-derived proinflammatory cytokines [139]. Therefore, inflammatory cytokines and GM can be seen as the key drivers regulating inflamed gut and it manifested bone disorder, which can be a potential clinical frontier to limit skeletal disease activity. 


\section{Closing Remarks}

During the past decade, plenty of research has focused on the skeletal abnormalities seen in IBD patients or animal models. Many risk factors including genetics and environmental elements are suggested to be associated with reduced bone mass in IBD patients. The various pathological mechanisms by which gut inflammation can exacerbate deterioration bone architectures are still under on-going debate. Development of a specific therapeutic strategy coping with a number of cohort effects (age, district, genetic background, disease activity, etc.) need to be considered by physicians and researchers [203,204]. Progress on experimental studies of animal models implicates dysbiosis of the intestinal microbiota, and its related inflammatory cytokines, is the key player driving systemic inflammation and subsequently resulting in bone loss. However, the understanding of pathogenic mechanisms defining interactions between bone and intestine is still at an early stage. More clinical and preclinical studies with well-designed human and animal models of IBD need to focus on interrogating major inflammatory mediators and key players that can influence gut-bone axis signaling in order to reduce the morbidity associated with gut-disease mediated bone loss.

Funding: This research was funded by NIH/NIAMS, grant number AR049192, AR054326, AR072623, AR0749920, and Shriners Hospital for Children, grant number \#86200.

Conflicts of Interest: The authors declare no conflict of interest.

\section{Abbreviations}

$\begin{array}{ll}\text { GALT } & \text { Gut-Associated Lymphoid Tissue } \\ \text { GI } & \text { Gastrointestinal } \\ \text { IBD } & \text { Inflammatory Bowel Disease } \\ \text { UC } & \text { Ulcerative Colitis } \\ \text { CD } & \text { Crohn's Disease } \\ \text { GM } & \text { Gut Microbiota } \\ \text { OP } & \text { Osteoporosis } \\ \text { BMD } & \text { Bone Mass/Mineral Density } \\ \text { OC } & \text { Osteoclast } \\ \text { OB } & \text { Osteoblast } \\ \text { IL } & \text { Interleukin } \\ \text { RANKL } & \text { Receptor Activator of Nuclear Factor Kappa-B Ligand } \\ \text { OPG } & \text { Osteoprotegerin } \\ \text { VDR } & \text { Vitamin D Receptor } \\ \text { PTH } & \text { Parathyroid Hormone } \\ \text { OCN } & \text { Osteocalcin } \\ \text { PINP } & \text { Procollagen type I N-terminal Propeptide } \\ \text { BW } & \text { Body Weight } \\ \text { CTX-I } & \text { Type I Collagen C-telopeptide } \\ \text { BM } & \text { Bone Marrow } \\ \text { OC.N. } & \text { Osteoclast Number } \\ \text { ALP } & \text { Alkaline Phosphatase } \\ \text { n.s. } & \text { No Significant Difference } \\ \text { BV/TV } & \text { Bone Volume/Total Volume } \\ \text { N.A. } & \text { Not Available } \\ \text { BV } & \text { Bone Volume } \\ \text { Tb.Th. } & \text { Trabecular Thickness } \\ \text { Tb.N. } & \text { Trabecular No. } \\ \text { ROS } & \text { Reactive Oxygen Species } \\ \text { NF-kB } & \text { Nuclear Factor Kappa-light-chain-enhancer of activated B cells } \\ \text { IEC } & \text { Intestinal Epithelial Cell } \\ \text { ILC } & \text { Innate Lymphoid Cells } \\ & \end{array}$




\begin{tabular}{ll} 
FXR & Farnesoid X Receptor \\
Mdr-2 & Multidrug Resistance-2 \\
GF & Germ Free \\
ConD-GF & Conventionalized Germ Free \\
IGF & Insulin-like Growth Factor \\
TJ & Tight Junction \\
SCFA & Short Chain Fatty Acid \\
TNBS & Trinitrobenzene Sulfonic Acid4 \\
BFR & Bone Formation Rate \\
BS & Bone Surface \\
OS & Osteocyte Surface \\
Ct.Ar. & Cortical Bone Area \\
Ct.Th. & Cortical Thickness \\
Ct.Ar/Tt.Ar & Cortical Bone Fraction \\
DSS & Dextran Sulfate Sodium \\
Conn.D & Connective Density \\
Tb.Sp. & Trabecular Space \\
Tg & Transgenic \\
SpA & Spondyloarthritis \\
STAT & Signal Transducer and Activator of Transcription \\
PSC & Primary Sclerosing Cholangitis \\
OVX & Ovariectomy \\
CONV-R & Conventionally Raised \\
GIP & Glucose-dependent Insulinotropic Polypeptide \\
BMMSC & Bone Marrow Mesenchymal Stem Cells \\
ER & Endoplasmic Reticulum \\
GWAS & Genome-wide association studies \\
UPR & Unfolded Proteins \\
TUDCA & Tauroursodeoxycholic Acid \\
& \\
\hline &
\end{tabular}

\section{References}

1. Forchielli, M.L.; Walker, W.A. The role of gut-associated lymphoid tissues and mucosal defence. Br. J. Nutr. 2005, 93, 41-48. [CrossRef] [PubMed]

2. Ott, C.; Scholmerich, J. Extraintestinal manifestations and complications in IBD. Nat. Rev. Gastroenterol. Hepatol. 2013, 10, 585. [CrossRef] [PubMed]

3. Rubin, D.T. Recent Research on Joint Pain and Arthritis in Patients With Inflammatory Bowel Disease. Gastroenterol. Hepatol. 2017, 13, 688-690.

4. Kelsall, B.L. Innate and adaptive mechanisms to control [corrected] pathological intestinal inflammation. J. Pathol. 2008, 214, 242-259. [CrossRef] [PubMed]

5. de Souza, H.S.; Fiocchi, C. Immunopathogenesis of IBD: Current state of the art. Nat. Rev. Gastroenterol. Hepatol. 2016, 13, 13-27. [CrossRef] [PubMed]

6. Vavricka, S.R.; Schoepfer, A.; Scharl, M.; Lakatos, P.L.; Navarini, A.; Rogler, G. Extraintestinal Manifestations of Inflammatory Bowel Disease. Inflamm. Bowel Dis. 2015, 21, 198-292. [CrossRef] [PubMed]

7. Ali, T.; Lam, D.; Bronze, M.S.; Humphrey, M.B. Osteoporosis in inflammatory bowel disease. Am. J. Med. 2009, 122, 599-604. [CrossRef]

8. Szafors, P.; Che, H.; Barnetche, T.; Morel, J.; Gaujoux-Viala, C.; Combe, B.; Lukas, C. Risk of fracture and low bone mineral density in adults with inflammatory bowel diseases. A systematic literature review with meta-analysis. Osteoporos. Int. 2018, 29, 2389-2397. [CrossRef]

9. Lima, C.A.; Lyra, A.C.; Mendes, C.M.C.; Lopes, M.B.; Coqueiro, F.G.; Rocha, R.; Santana, G.O. Bone mineral density and inflammatory bowel disease severity. Braz. J. Med. Biol. Res. 2017, 50, 6374. [CrossRef]

10. Bourikas, L.A.; Papadakis, K.A. Musculoskeletal manifestations of inflammatory bowel disease. Inflamm. Bowel Dis. 2009, 15, 191-524. [CrossRef]

11. Compston, J.E.; McClung, M.R.; Leslie, W.D. Osteoporosis. Lancet 2019, 393, 364-376. [CrossRef] 
12. Hudec, S.M.; Camacho, P.M. Secondary causes of osteoporosis. Endocr. Pract. 2013, 19, 120-128. [CrossRef] [PubMed]

13. Langdahl, B.; Ferrari, S.; Dempster, D.W. Bone modeling and remodeling: Potential as therapeutic targets for the treatment of osteoporosis. Ther. Adv. Musculoskelet. Dis. 2016, 8, 225-235. [CrossRef] [PubMed]

14. Colia, R.; Corrado, A.; Cantatore, F.P. Rheumatologic and extraintestinal manifestations of inflammatory bowel diseases. Ann. Med. 2016, 48,577-585. [CrossRef]

15. Yamamoto-Furusho, J.K.; Santiago-Hernandez, J.J.; Perez-Hernandez, N.; Ramirez-Fuentes, S.; Fragoso, J.M.; Vargas-Alarcon, G. Interleukin 1 beta (IL-1B) and IL-1 antagonist receptor (IL-1RN) gene polymorphisms are associated with the genetic susceptibility and steroid dependence in patients with ulcerative colitis. J. Clin. Gastroenterol. 2011, 45, 531-535. [CrossRef]

16. Vounotrypidis, P.; Kouklakis, G.; Anagnostopoulos, K.; Zezos, P.; Polychronidis, A.; Maltezos, E.; Efremidou, E.; Pitiakoudis, M.; Lyratzopoulos, N. Interleukin-1 associations in inflammatory bowel disease and the enteropathic seronegative spondylarthritis. Autoimmun. Highlights 2013, 4, 87-94. [CrossRef]

17. Dinarello, C.A. Interleukin-1 in the pathogenesis and treatment of inflammatory diseases. Blood 2011, 117, 3720-3732. [CrossRef]

18. Nemetz, A.; Toth, M.; Garcia-Gonzalez, M.A.; Zagoni, T.; Feher, J.; Pena, A.S.; Tulassay, Z. Allelic variation at the interleukin 1 beta gene is associated with decreased bone mass in patients with inflammatory bowel diseases. Gut 2001, 49, 644-649. [CrossRef]

19. Hugle, B.; Speth, F.; Haas, J.P. Inflammatory bowel disease following anti-interleukin-1-treatment in systemic juvenile idiopathic arthritis. Pediatric Rheumatol. Online J. 2017, 15, 16. [CrossRef]

20. Moschen, A.R.; Kaser, A.; Enrich, B.; Ludwiczek, O.; Gabriel, M.; Obrist, P.; Wolf, A.M.; Tilg, H. The RANKL/OPG system is activated in inflammatory bowel disease and relates to the state of bone loss. Gut 2005, 54, 479-487. [CrossRef]

21. Taranta, A.; Fortunati, D.; Longo, M.; Rucci, N.; Iacomino, E.; Aliberti, F.; Facciuto, E.; Migliaccio, S.; Bardella, M.T.; Dubini, A.; et al. Imbalance of osteoclastogenesis-regulating factors in patients with celiac disease. J. Bone Miner. Res. 2004, 19, 1112-1121. [CrossRef] [PubMed]

22. Horwood, N.J.; Elliott, J.; Martin, T.J.; Gillespie, M.T. IL-12 alone and in synergy with IL-18 inhibits osteoclast formation in vitro. J. Immunol. 2001, 166, 491-521. [CrossRef] [PubMed]

23. Krela-Kazmierczak, I.; Kaczmarek-Rys, M.; Szymczak, A.; Michalak, M.; Skrzypczak-Zielinska, M.; Drweska-Matelska, N.; Marcinkowska, M.; Eder, P.; Lykowska-Szuber, L.; Wysocka, E.; et al. Bone Metabolism and the c. $-223 \mathrm{C}>$ T Polymorphism in the 5'UTR Region of the Osteoprotegerin Gene in Patients with Inflammatory Bowel Disease. Calcif. Tissue Int. 2016, 99, 616-624. [CrossRef] [PubMed]

24. Fasciano, A.C.; Blutt, S.E.; Estes, M.K.; Mecsas, J. Induced Differentiation of M Cell-like Cells in Human Stem Cell-derived Ileal Enteroid Monolayers. J. Vis. Exp. 2019, 149, 59894. [CrossRef]

25. Schulte, C.M.; Dignass, A.U.; Goebell, H.; Roher, H.D.; Schulte, K.M. Genetic factors determine extent of bone loss in inflammatory bowel disease. Gastroenterology 2000, 119, 909-920. [CrossRef]

26. Todhunter, C.E.; Sutherland-Craggs, A.; Bartram, S.A.; Donaldson, P.T.; Daly, A.K.; Francis, R.M.; Mansfield, J.C.; Thompson, N.P. Influence of IL-6, COL1A1, and VDR gene polymorphisms on bone mineral density in Crohn's disease. Gut 2005, 54, 1579-1584. [CrossRef]

27. Szymczak-Tomczak, A.; Krela-Kazmierczak, I.; Kaczmarek-Rys, M.; Hryhorowicz, S.; Stawczyk-Eder, K.; Szalata, M.; Skrzypczak-Zielinska, M.; Lykowska-Szuber, L.; Eder, P.; Michalak, M.; et al. Vitamin D receptor (VDR) TaqI polymorphism, vitamin D and bone mineral density in patients with inflammatory bowel diseases. Adv. Clin. Exp. Med. 2019, 28, 955-960. [CrossRef]

28. Ahmad, I.; Jafar, T.; Mahdi, F.; Ameta, K.; Arshad, M.; Das, S.K.; Waliullah, S.; Rizvi, I.; Mahdi, A.A. Association of vitamin D receptor gene polymorphism (TaqI and Apa1) with bone mineral density in North Indian postmenopausal women. Gene 2018, 659, 123-127. [CrossRef]

29. Morrison, N.A.; Qi, J.C.; Tokita, A.; Kelly, P.J.; Crofts, L.; Nguyen, T.V.; Sambrook, P.N.; Eisman, J.A. Prediction of bone density from vitamin D receptor alleles. Nature 1994, 367, 284. [CrossRef]

30. Noble, C.L.; McCullough, J.; Ho, W.; Lees, C.W.; Nimmo, E.; Drummond, H.; Bear, S.; Hannan, J.; Millar, C.; Ralston, S.H.; et al. Low body mass not vitamin D receptor polymorphisms predict osteoporosis in patients with inflammatory bowel disease. Aliment. Pharmacol. Ther. 2008, 27, 588-596. [CrossRef]

31. Ohlsson, C.; Sjogren, K. Effects of the gut microbiota on bone mass. Trends Endocrinol. Metab. 2015, 26, 69-74. [CrossRef] [PubMed] 
32. Arvikar, S.L.; Fisher, M.C. Inflammatory bowel disease associated arthropathy. Curr. Rev. Musculoskelet. Med. 2011, 4, 123-131. [CrossRef] [PubMed]

33. Brakenhoff, L.K.; van der Heijde, D.M.; Hommes, D.W.; Huizinga, T.W.; Fidder, H.H. The joint-gut axis in inflammatory bowel diseases. J. Crohn's Colitis 2010, 4, 257-268. [CrossRef] [PubMed]

34. Schreiber, S.; Colombel, J.F.; Feagan, B.G.; Reich, K.; Deodhar, A.A.; McInnes, I.B.; Porter, B.; Das Gupta, A.; Pricop, L.; Fox, T.; et al. Incidence rates of inflammatory bowel disease in patients with psoriasis, psoriatic arthritis and ankylosing spondylitis treated with secukinumab: A retrospective analysis of pooled data from 21 clinical trials. Ann. Rheum. Dis. 2019, 78, 473-479. [CrossRef]

35. Muniz Pedrogo, D.A.; Chen, J.; Hillmann, B.; Jeraldo, P.; Al-Ghalith, G.; Taneja, V.; Davis, J.M.; Knights, D.; Nelson, H.; Faubion, W.A.; et al. An Increased Abundance of Clostridiaceae Characterizes Arthritis in Inflammatory Bowel Disease and Rheumatoid Arthritis: A Cross-sectional Study. Inflamm. Bowel Dis. 2019, 25, 902-913. [CrossRef]

36. Breban, M.; Tap, J.; Leboime, A.; Said-Nahal, R.; Langella, P.; Chiocchia, G.; Furet, J.P.; Sokol, H. Faecal microbiota study reveals specific dysbiosis in spondyloarthritis. Ann. Rheum. Dis. 2017, 76, 1614-1622. [CrossRef]

37. Hwang, C.; Ross, V.; Mahadevan, U. Micronutrient deficiencies in inflammatory bowel disease: From A to zinc. Inflamm. Bowel Dis. 2012, 18, 1961-1981. [CrossRef]

38. Demay, M.B. Mechanism of vitamin D receptor action. Ann. NY. Acad. Sci. 2006, 1068, 204-213. [CrossRef]

39. Abreu-Delgado, Y.; Isidro, R.A.; Torres, E.A.; Gonzalez, A.; Cruz, M.L.; Isidro, A.A.; Gonzalez-Keelan, C.I.; Medero, P.; Appleyard, C.B. Serum vitamin D and colonic vitamin D receptor in inflammatory bowel disease. World J. Gastroenterol. 2016, 22, 3581-3591. [CrossRef]

40. Liu, W.; Chen, Y.; Golan, M.A.; Annunziata, M.L.; Du, J.; Dougherty, U.; Kong, J.; Musch, M.; Huang, Y.; Pekow, J.; et al. Intestinal epithelial vitamin D receptor signaling inhibits experimental colitis. J. Clin. Investig. 2013, 123, 3983-3996. [CrossRef]

41. Chen, Y.; Du, J.; Zhang, Z.; Liu, T.; Shi, Y.; Ge, X.; Li, Y.C. MicroRNA-346 mediates tumor necrosis factor alpha-induced downregulation of gut epithelial vitamin $\mathrm{D}$ receptor in inflammatory bowel diseases. Inflamm. Bowel Dis. 2014, 20, 1910-1918. [CrossRef] [PubMed]

42. Wang, J.; Thingholm, L.B.; Skiecevičienè, J.; Rausch, P.; Kummen, M.; Hov, J.R.; Degenhardt, F.; Heinsen, F.A.; Rühlemann, M.C.; Szymczak, S.; et al. Genome-wide association analysis identifies variation in vitamin D receptor and other host factors influencing the gut microbiota. Nat. Genet. 2016, 48, 1396-1406. [CrossRef] [PubMed]

43. Del Pinto, R.; Pietropaoli, D.; Chandar, A.K.; Ferri, C.; Cominelli, F. Association Between Inflammatory Bowel Disease and Vitamin D Deficiency: A Systematic Review and Meta-analysis. Inflamm. Bowel Dis. 2015, 21, 2708-2717. [CrossRef] [PubMed]

44. Pappa, H.M.; Gordon, C.M.; Saslowsky, T.M.; Zholudev, A.; Horr, B.; Shih, M.C.; Grand, R.J. Vitamin D status in children and young adults with inflammatory bowel disease. Pediatrics 2006, 118, 1950-1961. [CrossRef]

45. Levin, A.D.; Wadhera, V.; Leach, S.T.; Woodhead, H.J.; Lemberg, D.A.; Mendoza-Cruz, A.C.; Day, A.S. Vitamin D deficiency in children with inflammatory bowel disease. Dig. Dis. Sci. 2011, 56, 830-836. [CrossRef]

46. Sentongo, T.A.; Semaeo, E.J.; Stettler, N.; Piccoli, D.A.; Stallings, V.A.; Zemel, B.S. Vitamin D status in children, adolescents, and young adults with Crohn disease. Am. J. Clin. Nutr. 2002, 76, 1077-1081. [CrossRef]

47. Laakso, S.; Valta, H.; Verkasalo, M.; Toiviainen-Salo, S.; Viljakainen, H.; Makitie, O. Impaired bone health in inflammatory bowel disease: A case-control study in 80 pediatric patients. Calcif. Tissue Int. 2012, 91, 121-130. [CrossRef]

48. Harpavat, M.; Greenspan, S.L.; O’Brien, C.; Chang, C.C.; Bowen, A.; Keljo, D.J. Altered bone mass in children at diagnosis of Crohn disease: A pilot study. J. Pediatric Gastroenterol. Nutr. 2005, 40, 295-300. [CrossRef]

49. Pappa, H.M.; Grand, R.J.; Gordon, C.M. Report on the vitamin D status of adult and pediatric patients with inflammatory bowel disease and its significance for bone health and disease. Inflamm. Bowel Dis. 2006, 12, 1162-1174. [CrossRef]

50. Del Pinto, R.; Ferri, C.; Cominelli, F. Vitamin D Axis in Inflammatory Bowel Diseases: Role, Current Uses and Future Perspectives. Int. J. Mol. Sci. 2017, 11, 2360. [CrossRef]

51. Neurath, M. Current and emerging therapeutic targets for IBD. Nat. Rev. Gastroenterol. Hepatol. 2017, 14, 688. [CrossRef] [PubMed] 
52. Van Staa, T.P.; Leufkens, H.G.; Cooper, C. The epidemiology of corticosteroid-induced osteoporosis: A meta-analysis. Osteoporos. Int. 2002, 13, 777-787. [CrossRef] [PubMed]

53. Buckley, L.; Humphrey, M.B. Glucocorticoid-Induced Osteoporosis. N. Engl. J. Med. 2018, 379, $2547-2556$. [CrossRef] [PubMed]

54. Pukajlo-Marczyk, A.; Jakubowska, A.; Bargenda-Lange, A.; Kilis-Pstrusinska, K.; Zwolinska, D. Assessment of the Concentration of Bone Metabolism Markers: Sclerostin and FGF-23 in Children with Idiopathic Nephrotic Syndrome Treated with Glucocorticosteroids. Dis. Markers 2019, 2019. [CrossRef]

55. Delucchi, A.; Toro, L.; Alzamora, R.; Barrientos, V.; Gonzalez, M.; Andaur, R.; Leon, P.; Villanueva, F.; Galindo, M.; Las Heras, F.; et al. Glucocorticoids Decrease Longitudinal Bone Growth in Pediatric Kidney Transplant Recipients by Stimulating the FGF23/FGFR3 Signaling Pathway. J. Bone Miner. Res. 2019, 34. [CrossRef]

56. El-Hodhod, M.A.; Hamdy, A.M.; Abbas, A.A.; Moftah, S.G.; Ramadan, A.A. Fibroblast growth factor 23 contributes to diminished bone mineral density in childhood inflammatory bowel disease. BMC Gastroenterol. 2012, 12, 44. [CrossRef]

57. Taurog, J.D.; Maika, S.D.; Satumtira, N.; Dorris, M.L.; McLean, I.L.; Yanagisawa, H.; Sayad, A.; Stagg, A.J.; Fox, G.M.; Le O’Brien, A.; et al. Inflammatory disease in HLA-B27 transgenic rats. Immunol. Rev. 1999, 169, 209-223.

58. Rauner, M.; Stupphann, D.; Haas, M.; Fert, I.; Glatigny, S.; Sipos, W.; Breban, M.; Pietschmann, P. The HLA-B27 transgenic rat, a model of spondyloarthritis, has decreased bone mineral density and increased RANKL to osteoprotegerin mRNA ratio. J. Rheumatol. 2009, 36, 120-126. [CrossRef]

59. Rauner, M.; Thiele, S.; Fert, I.; Araujo, L.M.; Layh-Schmitt, G.; Colbert, R.A.; Hofbauer, C.; Bernhardt, R.; Burki, A.; Schwiedrzik, J.; et al. Loss of bone strength in HLA-B27 transgenic rats is characterized by a high bone turnover and is mainly osteoclast-driven. Bone 2015, 75, 183-191. [CrossRef]

60. Papet, I.; El Yousfi, M.; Godin, J.P.; Mermoud, A.F.; Davicco, M.J.; Coxam, V.; Breuille, D.; Obled, C. HLA-B27 rats develop osteopaenia through increased bone resorption without any change in bone formation. $J$. Musculoskelet. Neuronal Interact. 2008, 8, 251-256.

61. Ansalone, C.; Utriainen, L.; Milling, S.; Goodyear, C.S. Role of Gut Inflammation in Altering the Monocyte Compartment and Its Osteoclastogenic Potential in HLA-B27-Transgenic Rats. Arthritis Rheumatol. 2017, 69, 1807-1815. [CrossRef] [PubMed]

62. Amling, M.; Priemel, M.; Holzmann, T.; Chapin, K.; Rueger, J.M.; Baron, R.; Demay, M.B. Rescue of the skeletal phenotype of vitamin $\mathrm{D}$ receptor-ablated mice in the setting of normal mineral ion homeostasis: Formal histomorphometric and biomechanical analyses. Endocrinology 1999, 140, 4982-4987. [CrossRef] [PubMed]

63. Masuyama, R.; Nakaya, Y.; Katsumata, S.; Kajita, Y.; Uehara, M.; Tanaka, S.; Sakai, A.; Kato, S.; Nakamura, T.; Suzuki, K. Dietary calcium and phosphorus ratio regulates bone mineralization and turnover in vitamin D receptor knockout mice by affecting intestinal calcium and phosphorus absorption. J. Bone Miner. Res. 2003, 18, 1217-1226. [CrossRef] [PubMed]

64. Xue, Y.; Fleet, J.C. Intestinal vitamin D receptor is required for normal calcium and bone metabolism in mice. Gastroenterology 2009, 136, 1317-1327. [CrossRef]

65. Kallay, E.; Pietschmann, P.; Toyokuni, S.; Bajna, E.; Hahn, P.; Mazzucco, K.; Bieglmayer, C.; Kato, S.; Cross, H.S. Characterization of a vitamin D receptor knockout mouse as a model of colorectal hyperproliferation and DNA damage. Carcinogenesis 2001, 22, 1429-1435. [CrossRef]

66. Kim, J.H.; Yamaori, S.; Tanabe, T.; Johnson, C.H.; Krausz, K.W.; Kato, S.; Gonzalez, F.J. Implication of intestinal VDR deficiency in inflammatory bowel disease. Biochim. Biophys. Acta 2013, 1830, 2118-2128. [CrossRef]

67. Lieben, L.; Masuyama, R.; Torrekens, S.; Van Looveren, R.; Schrooten, J.; Baatsen, P.; Lafage-Proust, M.H.; Dresselaers, T.; Feng, J.Q.; Bonewald, L.F.; et al. Normocalcemia is maintained in mice under conditions of calcium malabsorption by vitamin D-induced inhibition of bone mineralization. J. Clin. Investig. 2012, 122, 1803-1815. [CrossRef]

68. Dresner-Pollak, R.; Gelb, N.; Rachmilewitz, D.; Karmeli, F.; Weinreb, M. Interleukin 10-deficient mice develop osteopenia, decreased bone formation, and mechanical fragility of long bones. Gastroenterology 2004, 127, 792-801. [CrossRef] 
69. Ciucci, T.; Ibanez, L.; Boucoiran, A.; Birgy-Barelli, E.; Pene, J.; Abou-Ezzi, G.; Arab, N.; Rouleau, M.; Hebuterne, X.; Yssel, H.; et al. Bone marrow Th17 TNFalpha cells induce osteoclast differentiation, and link bone destruction to IBD. Gut 2015, 64, 1072-1081. [CrossRef]

70. Thurston, R.D.; Larmonier, C.B.; Majewski, P.M.; Ramalingam, R.; Midura-Kiela, M.; Laubitz, D.; Vandewalle, A.; Besselsen, D.G.; Muhlbauer, M.; Jobin, C.; et al. Tumor necrosis factor and interferon-gamma down-regulate Klotho in mice with colitis. Gastroenterology 2010, 138, 1384-1394. [CrossRef]

71. Sadlack, B.; Merz, H.; Schorle, H.; Schimpl, A.; Feller, A.C.; Horak, I. Ulcerative colitis-like disease in mice with a disrupted interleukin-2 gene. Cell 1993, 75, 253-261. [CrossRef]

72. Ashcroft, A.J.; Cruickshank, S.M.; Croucher, P.I.; Perry, M.J.; Rollinson, S.; Lippitt, J.M.; Child, J.A.; Dunstan, C.; Felsburg, P.J.; Morgan, G.J.; et al. Colonic dendritic cells, intestinal inflammation, and T cell-mediated bone destruction are modulated by recombinant osteoprotegerin. Immunity 2003, 19, 849-861. [CrossRef]

73. Kontoyiannis, D.; Pasparakis, M.; Pizarro, T.T.; Cominelli, F.; Kollias, G. Impaired on/off regulation of TNF biosynthesis in mice lacking TNF AU-rich elements: Implications for joint and gut-associated immunopathologies. Immunity 1999, 10, 387-398. [CrossRef]

74. Ernst, M.; Inglese, M.; Waring, P.; Campbell, I.K.; Bao, S.; Clay, F.J.; Alexander, W.S.; Wicks, I.P.; Tarlinton, D.M.; Novak, U.; et al. Defective gp130-mediated signal transducer and activator of transcription (STAT) signaling results in degenerative joint disease, gastrointestinal ulceration, and failure of uterine implantation. J. Exp. Med. 2001, 194, 189-203. [CrossRef] [PubMed]

75. Sims, N.A.; Jenkins, B.J.; Quinn, J.M.; Nakamura, A.; Glatt, M.; Gillespie, M.T.; Ernst, M.; Martin, T.J. Glycoprotein 130 regulates bone turnover and bone size by distinct downstream signaling pathways. J. Clin. Investig. 2004, 113, 379-389. [CrossRef]

76. Welte, T.; Zhang, S.S.; Wang, T.; Zhang, Z.; Hesslein, D.G.; Yin, Z.; Kano, A.; Iwamoto, Y.; Li, E.; Craft, J.E.; et al. STAT3 deletion during hematopoiesis causes Crohn's disease-like pathogenesis and lethality: A critical role of STAT3 in innate immunity. Proc. Natl. Acad. Sci. USA. 2003, 100, 1879-1884. [CrossRef]

77. Mantel, C.; Messina-Graham, S.; Moh, A.; Cooper, S.; Hangoc, G.; Fu, X.Y.; Broxmeyer, H.E. Mouse hematopoietic cell-targeted STAT3 deletion: Stem/progenitor cell defects, mitochondrial dysfunction, ROS overproduction, and a rapid aging-like phenotype. Blood 2012, 120, 2589-2599. [CrossRef]

78. Matmati, M.; Jacques, P.; Maelfait, J.; Verheugen, E.; Kool, M.; Sze, M.; Geboes, L.; Louagie, E.; Mc Guire, C.; Vereecke, L.; et al. A20 (TNFAIP3) deficiency in myeloid cells triggers erosive polyarthritis resembling rheumatoid arthritis. Nat. Genet. 2011, 43, 908-912. [CrossRef]

79. Vereecke, L.; Vieira-Silva, S.; Billiet, T.; van Es, J.H.; Mc Guire, C.; Slowicka, K.; Sze, M.; van den Born, M.; De Hertogh, G.; Clevers, H.; et al. A20 controls intestinal homeostasis through cell-specific activities. Nat. Commun. 2014, 5, 5103. [CrossRef]

80. Ke, K.; Chen, T.H.; Arra, M.; Mbalaviele, G.; Swarnkar, G.; Abu-Amer, Y. Attenuation of NF-kappaB in Intestinal Epithelial Cells Is Sufficient to Mitigate the Bone Loss Comorbidity of Experimental Mouse Colitis. J. Bone Miner. Res. 2019, 34, 1880-1893. [CrossRef]

81. Guma, M.; Stepniak, D.; Shaked, H.; Spehlmann, M.E.; Shenouda, S.; Cheroutre, H.; Vicente-Suarez, I.; Eckmann, L.; Kagnoff, M.F.; Karin, M.; et al. Constitutive intestinal NF-kappaB does not trigger destructive inflammation unless accompanied by MAPK activation. J. Exp. Med. 2011, 208, 1889-1900. [CrossRef] [PubMed]

82. Vlantis, K.; Wullaert, A.; Sasaki, Y.; Schmidt-Supprian, M.; Rajewsky, K.; Roskams, T.; Pasparakis, M. Constitutive IKK2 activation in intestinal epithelial cells induces intestinal tumors in mice. J. Clin. Investig. 2011, 121, 2781-2793. [CrossRef] [PubMed]

83. Maran, R.R.; Thomas, A.; Roth, M.; Sheng, Z.; Esterly, N.; Pinson, D.; Gao, X.; Zhang, Y.; Ganapathy, V.; Gonzalez, F.J.; et al. Farnesoid $X$ receptor deficiency in mice leads to increased intestinal epithelial cell proliferation and tumor development. J. Pharm. Exp. Ther. 2009, 328, 469-477. [CrossRef] [PubMed]

84. Cho, S.W.; An, J.H.; Park, H.; Yang, J.Y.; Choi, H.J.; Kim, S.W.; Park, Y.J.; Kim, S.Y.; Yim, M.; Baek, W.Y.; et al. Positive regulation of osteogenesis by bile acid through FXR. J. Bone Miner. Res. 2013, 28, 2109-2121. [CrossRef] [PubMed]

85. Zheng, T.; Kang, J.H.; Sim, J.S.; Kim, J.W.; Koh, J.T.; Shin, C.S.; Lim, H.; Yim, M. The farnesoid X receptor negatively regulates osteoclastogenesis in bone remodeling and pathological bone loss. Oncotarget 2017, 8, 76558-76573. [CrossRef] 
86. Liao, L.; Schneider, K.M.; Galvez, E.J.C.; Frissen, M.; Marschall, H.U.; Su, H.; Hatting, M.; Wahlstrom, A.; Haybaeck, J.; Puchas, P.; et al. Intestinal dysbiosis augments liver disease progression via NLRP3 in a murine model of primary sclerosing cholangitis. Gut 2019, 68, 1477-1492. [CrossRef]

87. Schmidt, T.; Schwinge, D.; Rolvien, T.; Jeschke, A.; Schmidt, C.; Neven, M.; Butscheidt, S.; Kriz, M.; Kunzmann, L.; Mussawy, H.; et al. Th17 cell frequency is associated with low bone mass in primary sclerosing cholangitis. J. Hepatol. 2019, 70, 941-953. [CrossRef]

88. Sjogren, K.; Engdahl, C.; Henning, P.; Lerner, U.H.; Tremaroli, V.; Lagerquist, M.K.; Backhed, F.; Ohlsson, C. The gut microbiota regulates bone mass in mice. J. Bone Miner. Res. 2012, 27, 1357-1367. [CrossRef]

89. Novince, C.M.; Whittow, C.R.; Aartun, J.D.; Hathaway, J.D.; Poulides, N.; Chavez, M.B.; Steinkamp, H.M.; Kirkwood, K.A.; Huang, E.; Westwater, C.; et al. Commensal Gut Microbiota Immunomodulatory Actions in Bone Marrow and Liver have Catabolic Effects on Skeletal Homeostasis in Health. Sci. Rep. 2017, 7, 5747. [CrossRef]

90. Yan, J.; Herzog, J.W.; Tsang, K.; Brennan, C.A.; Bower, M.A.; Garrett, W.S.; Sartor, B.R.; Aliprantis, A.O.; Charles, J.F. Gut microbiota induce IGF-1 and promote bone formation and growth. Proc. Natl. Acad. Sci. USA. 2016, 113, 7554-7563. [CrossRef]

91. Metzger, C.E.; Narayanan, A.; Zawieja, D.C.; Bloomfield, S.A. Inflammatory Bowel Disease in a Rodent Model Alters Osteocyte Protein Levels Controlling Bone Turnover. J. Bone Miner. Res. 2017, 32, 802-813. [CrossRef] [PubMed]

92. Radhakrishnan, V.M.; Ramalingam, R.; Larmonier, C.B.; Thurston, R.D.; Laubitz, D.; Midura-Kiela, M.T.; McFadden, R.M.; Kuro, O.M.; Kiela, P.R.; Ghishan, F.K.; et al. Post-translational loss of renal TRPV5 calcium channel expression, $\mathrm{Ca}(2+)$ wasting, and bone loss in experimental colitis. Gastroenterology 2013, 145, 613-624. [CrossRef] [PubMed]

93. Harris, L.; Senagore, P.; Young, V.B.; McCabe, L.R. Inflammatory bowel disease causes reversible suppression of osteoblast and chondrocyte function in mice. Am. J. Physiol. Gastrointest. Liver Physiol. 2009, 296, 1020-1029. [CrossRef] [PubMed]

94. Oz, H.S.; Ebersole, J.L. A novel murine model for chronic inflammatory alveolar bone loss. J. Periodontal. Res. 2010, 45, 94-99. [CrossRef] [PubMed]

95. Irwin, R.; Raehtz, S.; Parameswaran, N.; McCabe, L.R. Intestinal inflammation without weight loss decreases bone density and growth. Am. J. Physiol. Regul. Integr. Comp. Physiol. 2016, 311, 1149-1157. [CrossRef]

96. Byrne, F.R.; Morony, S.; Warmington, K.; Geng, Z.; Brown, H.L.; Flores, S.A.; Fiorino, M.; Yin, S.L.; Hill, D.; Porkess, V.; et al. CD4 + CD45RBHi T cell transfer induced colitis in mice is accompanied by osteopenia which is treatable with recombinant human osteoprotegerin. Gut 2005, 54, 78-86. [CrossRef]

97. Ibanez, L.; Abou-Ezzi, G.; Ciucci, T.; Amiot, V.; Belaid, N.; Obino, D.; Mansour, A.; Rouleau, M.; Wakkach, A.; Blin-Wakkach, C.; et al. Inflammatory Osteoclasts Prime TNFalpha-Producing CD4(+) T Cells and Express CX3 CR1. J. Bone Miner. Res. 2016, 31, 1899-1908. [CrossRef]

98. Brown, M.A.; Kenna, T.; Wordsworth, B.P. Genetics of ankylosing spondylitis-insights into pathogenesis. Nat. Rev. Rheumatol. 2016, 12, 81-91. [CrossRef]

99. Ossum, A.M.; Palm, O.; Lunder, A.K.; Cvancarova, M.; Banitalebi, H.; Negard, A.; Hoie, O.; Henriksen, M.; Moum, B.A.; Hoivik, M.L.; et al. Ankylosing Spondylitis and Axial Spondyloarthritis in Patients With Long-term Inflammatory Bowel Disease: Results From 20 Years of Follow-up in the IBSEN Study. J. Crohn's Colitis 2018, 12, 96-104. [CrossRef]

100. Olivieri, I.; Cantini, F.; Castiglione, F.; Felice, C.; Gionchetti, P.; Orlando, A.; Salvarani, C.; Scarpa, R.; Vecchi, M.; Armuzzi, A.; et al. Italian Expert Panel on the management of patients with coexisting spondyloarthritis and inflammatory bowel disease. Autoimmun. Rev. 2014, 13, 822-830. [CrossRef]

101. Salvarani, C.; Fries, W. Clinical features and epidemiology of spondyloarthritides associated with inflammatory bowel disease. World J. Gastroenterol. 2009, 15, 2449-2455. [CrossRef] [PubMed]

102. Orchard, T.R.; Wordsworth, B.P.; Jewell, D.P. Peripheral arthropathies in inflammatory bowel disease: Their articular distribution and natural history. Gut 1998, 42, 387-391. [CrossRef] [PubMed]

103. Fragoulis, G.E.; Liava, C.; Daoussis, D.; Akriviadis, E.; Garyfallos, A.; Dimitroulas, T. Inflammatory bowel diseases and spondyloarthropathies: From pathogenesis to treatment. World J. Gastroenterol. 2019, 25, 2162-2176. [CrossRef] [PubMed] 
104. Taurog, J.D.; Richardson, J.A.; Croft, J.T.; Simmons, W.A.; Zhou, M.; Fernandez-Sueiro, J.L.; Balish, E.; Hammer, R.E. The germfree state prevents development of gut and joint inflammatory disease in HLA-B27 transgenic rats. J. Exp. Med. 1994, 180, 2359-2364. [CrossRef]

105. Yamamoto, Y.; Yoshizawa, T.; Fukuda, T.; Shirode-Fukuda, Y.; Yu, T.; Sekine, K.; Sato, T.; Kawano, H.; Aihara, K.; Nakamichi, Y.; et al. Vitamin D receptor in osteoblasts is a negative regulator of bone mass control. Endocrinology 2013, 154, 1008-1020. [CrossRef]

106. Nakamichi, Y.; Udagawa, N.; Suda, T.; Takahashi, N. Mechanisms involved in bone resorption regulated by vitamin D. J. Steroid Biochem. Mol. Biol. 2018, 177, 70-76. [CrossRef]

107. Evans, K.E.; Fox, S.W. Interleukin-10 inhibits osteoclastogenesis by reducing NFATc1 expression and preventing its translocation to the nucleus. BMC Cell Biol. 2007, 8, 4. [CrossRef]

108. Mohamed, S.G.; Sugiyama, E.; Shinoda, K.; Taki, H.; Hounoki, H.; Abdel-Aziz, H.O.; Maruyama, M.; Kobayashi, M.; Ogawa, H.; Miyahara, T.; et al. Interleukin-10 inhibits RANKL-mediated expression of NFATc1 in part via suppression of c-Fos and c-Jun in RAW264.7 cells and mouse bone marrow cells. Bone 2007, 41, 592-602. [CrossRef]

109. Nelson, B.H. IL-2, regulatory T cells, and tolerance. J. Immunol. 2004, 172, 3983-3988. [CrossRef]

110. Ward, N.C.; Yu, A.; Moro, A.; Ban, Y.; Chen, X.; Hsiung, S.; Keegan, J.; Arbanas, J.M.; Loubeau, M.; Thankappan, A.; et al. IL-2/CD25: A Long-Acting Fusion Protein That Promotes Immune Tolerance by Selectively Targeting the IL-2 Receptor on Regulatory T Cells. J. Immunol. 2018, 201, 2579-2592. [CrossRef]

111. Josien, R.; Li, H.L.; Ingulli, E.; Sarma, S.; Wong, B.R.; Vologodskaia, M.; Steinman, R.M.; Choi, Y. TRANCE, a tumor necrosis factor family member, enhances the longevity and adjuvant properties of dendritic cells in vivo. J. Exp. Med. 2000, 191, 495-502. [CrossRef] [PubMed]

112. Naka, T.; Kishimoto, T. Joint disease caused by defective gp130-mediated STAT signaling. Arthritis Res 2002, 4, 154-156. [CrossRef] [PubMed]

113. Jenkins, B.J.; Roberts, A.W.; Greenhill, C.J.; Najdovska, M.; Lundgren-May, T.; Robb, L.; Grail, D.; Ernst, M. Pathologic consequences of STAT3 hyperactivation by IL-6 and IL-11 during hematopoiesis and lymphopoiesis. Blood 2007, 109, 2380-2388. [CrossRef] [PubMed]

114. Ellmark, P.; Ingvarsson, J.; Carlsson, A.; Lundin, B.S.; Wingren, C.; Borrebaeck, C.A. Identification of protein expression signatures associated with Helicobacter pylori infection and gastric adenocarcinoma using recombinant antibody microarrays. Mol. Cell. Proteom. 2006, 5, 1638-1646. [CrossRef] [PubMed]

115. Nguyen, P.M.; Putoczki, T.L.; Ernst, M. STAT3-Activating Cytokines: A Therapeutic Opportunity for Inflammatory Bowel Disease? J. Interferon Cytokine Res. 2015, 35, 340-350. [CrossRef] [PubMed]

116. Hillmer, E.J.; Zhang, H.; Li, H.S.; Watowich, S.S. STAT3 signaling in immunity. Cytokine Growth Factor Rev. 2016, 31, 1-15. [CrossRef]

117. Zhang, Z.; Welte, T.; Troiano, N.; Maher, S.E.; Fu, X.Y.; Bothwell, A.L. Osteoporosis with increased osteoclastogenesis in hematopoietic cell-specific STAT3-deficient mice. Biochem. Biophys. Res. Commun. 2005, 328, 800-807. [CrossRef]

118. Zaidi, D.; Wine, E. Regulation of Nuclear Factor Kappa-Light-Chain-Enhancer of Activated B Cells (NF-kappabeta) in Inflammatory Bowel Diseases. Front. Pediatr. 2018, 6, 317. [CrossRef]

119. Abu-Amer, Y. NF-kappaB signaling and bone resorption. Osteoporos. Int. 2013, 24, 2377-2386. [CrossRef]

120. Lee, E.G.; Boone, D.L.; Chai, S.; Libby, S.L.; Chien, M.; Lodolce, J.P.; Ma, A. Failure to regulate TNF-induced NF-kappaB and cell death responses in A20-deficient mice. Science 2000, 289, 2350-2354. [CrossRef]

121. Han, C.Y. Update on FXR Biology: Promising Therapeutic Target? Int. J. Mol. Sci. 2018, 19, 2069. [CrossRef] [PubMed]

122. Popp, A.W.; Isenegger, J.; Buergi, E.M.; Buergi, U.; Lippuner, K. Glucocorticosteroid-induced spinal osteoporosis: Scientific update on pathophysiology and treatment. Eur. Spine J. 2006, 15, 1035-1049. [CrossRef] [PubMed]

123. Parseus, A.; Sommer, N.; Sommer, F.; Caesar, R.; Molinaro, A.; Stahlman, M.; Greiner, T.U.; Perkins, R.; Backhed, F. Microbiota-induced obesity requires farnesoid X receptor. Gut 2017, 66, 429-437. [CrossRef] [PubMed]

124. Hartmann, P.; Hochrath, K.; Horvath, A.; Chen, P.; Seebauer, C.T.; Llorente, C.; Wang, L.; Alnouti, Y.; Fouts, D.E.; Starkel, P.; et al. Modulation of the intestinal bile acid/farnesoid X receptor/fibroblast growth factor 15 axis improves alcoholic liver disease in mice. Hepatology 2018, 67, 2150-2166. [CrossRef] 
125. Inagaki, T.; Moschetta, A.; Lee, Y.K.; Peng, L.; Zhao, G.; Downes, M.; Yu, R.T.; Shelton, J.M.; Richardson, J.A.; Repa, J.J.; et al. Regulation of antibacterial defense in the small intestine by the nuclear bile acid receptor. Proc. Natl. Acad. Sci. USA. 2006, 103, 3920-3925. [CrossRef]

126. Borst, P.; Elferink, R.O. Mammalian ABC transporters in health and disease. Annu. Rev. Biochem. 2002, 71, 537-592. [CrossRef]

127. Ruetz, S.; Gros, P. Phosphatidylcholine translocase: A physiological role for the mdr2 gene. Cell 1994, 77, 1071-1081. [CrossRef]

128. Fickert, P.; Pollheimer, M.J.; Beuers, U.; Lackner, C.; Hirschfield, G.; Housset, C.; Keitel, V.; Schramm, C.; Marschall, H.U.; Karlsen, T.H.; et al. Characterization of animal models for primary sclerosing cholangitis (PSC). J. Hepatol. 2014, 60, 1290-1303. [CrossRef]

129. Giordano, D.M.; Pinto, C.; Maroni, L.; Benedetti, A.; Marzioni, M. Inflammation and the Gut-Liver Axis in the Pathophysiology of Cholangiopathies. Int. J. Mol. Sci. 2018, 19, 3003. [CrossRef]

130. Angulo, P.; Grandison, G.A.; Fong, D.G.; Keach, J.C.; Lindor, K.D.; Bjornsson, E.; Koch, A. Bone disease in patients with primary sclerosing cholangitis. Gastroenterology 2011, 140, 180-188. [CrossRef]

131. Katt, J.; Schwinge, D.; Schoknecht, T.; Quaas, A.; Sobottka, I.; Burandt, E.; Becker, C.; Neurath, M.F.; Lohse, A.W.; Herkel, J.; et al. Increased T helper type 17 response to pathogen stimulation in patients with primary sclerosing cholangitis. Hepatology 2013, 58, 1084-1093. [CrossRef] [PubMed]

132. Kennedy, E.A.; King, K.Y.; Baldridge, M.T. Mouse Microbiota Models: Comparing Germ-Free Mice and Antibiotics Treatment as Tools for Modifying Gut Bacteria. Front. Physiol. 2018, 9, 1534. [CrossRef] [PubMed]

133. Macpherson, A.J.; Harris, N.L. Interactions between commensal intestinal bacteria and the immune system. Nat. Rev. Immunol. 2004, 4, 478-485. [CrossRef] [PubMed]

134. Smith, K.; McCoy, K.D.; Macpherson, A.J. Use of axenic animals in studying the adaptation of mammals to their commensal intestinal microbiota. Semin. Immunol. 2007, 19, 59-69. [CrossRef] [PubMed]

135. Cho, I.; Yamanishi, S.; Cox, L.; Methe, B.A.; Zavadil, J.; Li, K.; Gao, Z.; Mahana, D.; Raju, K.; Teitler, I.; et al. Antibiotics in early life alter the murine colonic microbiome and adiposity. Nature 2012, 488, 621-626. [CrossRef] [PubMed]

136. Seino, Y.; Fukushima, M.; Yabe, D. GIP and GLP-1, the two incretin hormones: Similarities and differences. J. Diabetes Investig. 2010, 1, 8-23. [CrossRef] [PubMed]

137. Bollag, R.J.; Zhong, Q.; Ding, K.H.; Phillips, P.; Zhong, L.; Qin, F.; Cranford, J.; Mulloy, A.L.; Cameron, R.; Isales, C.M.; et al. Glucose-dependent insulinotropic peptide is an integrative hormone with osteotropic effects. Mol. Cell. Endocrinol. 2001, 177, 35-41. [CrossRef]

138. Britton, R.A.; Irwin, R.; Quach, D.; Schaefer, L.; Zhang, J.; Lee, T.; Parameswaran, N.; McCabe, L.R. Probiotic, L. Reuteri treatment prevents bone loss in a menopausal ovariectomized mouse model. J. Cell. Physiol. 2014, 229, 1822-1830. [CrossRef]

139. Li, J.Y.; Chassaing, B.; Tyagi, A.M.; Vaccaro, C.; Luo, T.; Adams, J.; Darby, T.M.; Weitzmann, M.N.; Mulle, J.G.; Gewirtz, A.T.; et al. Sex steroid deficiency-associated bone loss is microbiota dependent and prevented by probiotics. J. Clin. Investig. 2016, 126, 2049-2063. [CrossRef]

140. Ohlsson, C.; Engdahl, C.; Fak, F.; Andersson, A.; Windahl, S.H.; Farman, H.H.; Moverare-Skrtic, S.; Islander, U.; Sjogren, K. Probiotics protect mice from ovariectomy-induced cortical bone loss. PLoS ONE 2014, 9, 92368. [CrossRef]

141. Wirtz, S.; Neufert, C.; Weigmann, B.; Neurath, M.F. Chemically induced mouse models of intestinal inflammation. Nat. Protoc. 2007, 2, 541-546. [CrossRef] [PubMed]

142. Kiesler, P.; Fuss, I.J.; Strober, W. Experimental Models of Inflammatory Bowel Diseases. Cell. Mol. Gastroenterol. Hepatol. 2015, 1, 154-170. [CrossRef] [PubMed]

143. Lin, C.L.; Moniz, C.; Chambers, T.J.; Chow, J.W. Colitis causes bone loss in rats through suppression of bone formation. Gastroenterology 1996, 111, 1263-1271. [CrossRef] [PubMed]

144. Eichele, D.D.; Kharbanda, K.K. Dextran sodium sulfate colitis murine model: An indispensable tool for advancing our understanding of inflammatory bowel diseases pathogenesis. World J. Gastroenterol. 2017, 23, 6016-6029. [CrossRef]

145. Ghishan, F.K.; Kiela, P.R. Advances in the understanding of mineral and bone metabolism in inflammatory bowel diseases. Am. J. Physiol. Gastrointest. Liver Physiol. 2011, 300, 191-201. [CrossRef]

146. Terzoudis, S.; Zavos, C.; Koutroubakis, I.E. The bone and fat connection in inflammatory bowel diseases. Inflamm. Bowel Dis. 2014, 20, 2207-2217. [CrossRef] 
147. Bryant, R.V.; Schultz, C.G.; Ooi, S.; Goess, C.; Costello, S.P.; Vincent, A.D.; Schoeman, S.N.; Lim, A.; Bartholomeusz, F.D.; Travis, S.P.L.; et al. Obesity in Inflammatory Bowel Disease: Gains in Adiposity despite High Prevalence of Myopenia and Osteopenia. Nutrients 2018, 10, 1192. [CrossRef]

148. Kredel, L.I.; Siegmund, B. Adipose-tissue and intestinal inflammation-Visceral obesity and creeping fat. Front. Immunol. 2014, 5, 462. [CrossRef]

149. Hamdani, G.; Gabet, Y.; Rachmilewitz, D.; Karmeli, F.; Bab, I.; Dresner-Pollak, R. Dextran sodium sulfate-induced colitis causes rapid bone loss in mice. Bone 2008, 43, 945-950. [CrossRef]

150. Qi, M.; Zhang, L.; Ma, Y.; Shuai, Y.; Li, L.; Luo, K.; Liu, W.; Jin, Y. Autophagy Maintains the Function of Bone Marrow Mesenchymal Stem Cells to Prevent Estrogen Deficiency-Induced Osteoporosis. Theranostics 2017, 7, 4498-4516. [CrossRef]

151. Ostanin, D.V.; Bao, J.; Koboziev, I.; Gray, L.; Robinson-Jackson, S.A.; Kosloski-Davidson, M.; Price, V.H.; Grisham, M.B. T cell transfer model of chronic colitis: Concepts, considerations, and tricks of the trade. Am. J. Physiol. Gastrointest. Liver Physiol. 2009, 296, 135-146. [CrossRef] [PubMed]

152. Allaire, J.M.; Crowley, S.M.; Law, H.T.; Chang, S.Y.; Ko, H.J.; Vallance, B.A. The Intestinal Epithelium: Central Coordinator of Mucosal Immunity. Trends Immunol. 2018, 39, 677-696. [CrossRef] [PubMed]

153. Dahan, S.; Roth-Walter, F.; Arnaboldi, P.; Agarwal, S.; Mayer, L. Epithelia: Lymphocyte interactions in the gut. Immunol. Rev. 2007, 215, 243-253. [CrossRef] [PubMed]

154. Zeissig, S.; Burgel, N.; Gunzel, D.; Richter, J.; Mankertz, J.; Wahnschaffe, U.; Kroesen, A.J.; Zeitz, M.; Fromm, M.; Schulzke, J.D.; et al. Changes in expression and distribution of claudin 2, 5 and 8 lead to discontinuous tight junctions and barrier dysfunction in active Crohn's disease. Gut 2007, 56, 61-72. [CrossRef] [PubMed]

155. Rios-Arce, N.D.; Collins, F.L.; Schepper, J.D.; Steury, M.D.; Raehtz, S.; Mallin, H.; Schoenherr, D.T.; Parameswaran, N.; McCabe, L.R. Epithelial Barrier Function in Gut-Bone Signaling. Adv. Exp. Med. Biol. 2017, 1033, 151-183. [PubMed]

156. Kurl, S.; Heinonen, K.; Lansimies, E.; Launiala, K. Determinants of bone mineral density in prematurely born children aged 6-7 years. Acta Paediatr. 1998, 87, 650-653. [CrossRef]

157. Takada, M.; Shimada, M.; Hosono, S.; Tauchi, M.; Minato, M.; Takahashi, S.; Okuni, M.; Takeuchi, S. Trace elements and mineral requirements for very low birth weight infants in rickets of prematurity. Early Hum. Dev. 1992, 29, 333-338. [CrossRef]

158. Halpern, M.D.; Denning, P.W. The role of intestinal epithelial barrier function in the development of NEC. Tissue Barriers 2015, 3. [CrossRef]

159. Ma, T.Y.; Iwamoto, G.K.; Hoa, N.T.; Akotia, V.; Pedram, A.; Boivin, M.A.; Said, H.M. TNF-alpha-induced increase in intestinal epithelial tight junction permeability requires NF-kappa B activation. Am. J. Physiol. Gastrointest. Liver Physiol. 2004, 286, 367-376. [CrossRef]

160. Al-Sadi, R.; Guo, S.; Ye, D.; Rawat, M.; Ma, T.Y. TNF-alpha Modulation of Intestinal Tight Junction Permeability Is Mediated by NIK/IKK-alpha Axis Activation of the Canonical NF-kappaB Pathway. Am. J. Pathol. 2016, 186, 1151-1165. [CrossRef]

161. Al-Sadi, R.M.; Ma, T.Y. IL-1beta causes an increase in intestinal epithelial tight junction permeability. J. Immunol. 2007, 178, 4641-4649. [CrossRef] [PubMed]

162. Al-Sadi, R.; Ye, D.; Said, H.M.; Ma, T.Y. IL-1beta-induced increase in intestinal epithelial tight junction permeability is mediated by MEKK-1 activation of canonical NF-kappaB pathway. Am. J. Pathol. 2010, 177, 2310-2322. [CrossRef] [PubMed]

163. Jostins, L.; Ripke, S.; Weersma, R.K.; Duerr, R.H.; McGovern, D.P.; Hui, K.Y.; Lee, J.C.; Schumm, L.P.; Sharma, Y.; Anderson, C.A.; et al. Host-microbe interactions have shaped the genetic architecture of inflammatory bowel disease. Nature 2012, 491, 119-124. [CrossRef] [PubMed]

164. Cleynen, I.; Boucher, G.; Jostins, L.; Schumm, L.P.; Zeissig, S.; Ahmad, T.; Andersen, V.; Andrews, J.M.; Annese, V.; Brand, S.; et al. Inherited determinants of Crohn's disease and ulcerative colitis phenotypes: A genetic association study. Lancet 2016, 387, 156-167. [CrossRef]

165. Kaser, A.; Lee, A.H.; Franke, A.; Glickman, J.N.; Zeissig, S.; Tilg, H.; Nieuwenhuis, E.E.; Higgins, D.E.; Schreiber, S.; Glimcher, L.H.; et al. XBP1 links ER stress to intestinal inflammation and confers genetic risk for human inflammatory bowel disease. Cell 2008, 134, 743-756. [CrossRef] [PubMed] 
166. Zhang, H.S.; Chen, Y.; Fan, L.; Xi, Q.L.; Wu, G.H.; Li, X.X.; Yuan, T.L.; He, S.Q.; Yu, Y.; Shao, M.L.; et al. The Endoplasmic Reticulum Stress Sensor IRE1alpha in Intestinal Epithelial Cells Is Essential for Protecting against Colitis. J. Biol. Chem. 2015, 290, 15327-15336. [CrossRef]

167. Garg, A.D.; Kaczmarek, A.; Krysko, O.; Vandenabeele, P.; Krysko, D.V.; Agostinis, P. ER stress-induced inflammation: Does it aid or impede disease progression? Trends Mol. Med. 2012, 18, 589-598. [CrossRef]

168. Navid, F.; Colbert, R.A. Causes and consequences of endoplasmic reticulum stress in rheumatic disease. Nat. Rev. Rheumatol. 2017, 13, 25-40. [CrossRef]

169. Rahmati, M.; Moosavi, M.A.; McDermott, M.F. ER Stress: A Therapeutic Target in Rheumatoid Arthritis? Trends Pharmacol. Sci. 2018, 39, 610-623. [CrossRef]

170. Scheiber, A.L.; Guess, A.J.; Kaito, T.; Abzug, J.M.; Enomoto-Iwamoto, M.; Leikin, S.; Iwamoto, M.; Otsuru, S. Endoplasmic reticulum stress is induced in growth plate hypertrophic chondrocytes in G610C mouse model of osteogenesis imperfecta. Biochem. Biophys. Res. Commun. 2019, 509, 235-240. [CrossRef]

171. Yoo, S.A.; You, S.; Yoon, H.J.; Kim, D.H.; Kim, H.S.; Lee, K.; Ahn, J.H.; Hwang, D.; Lee, A.S.; Kim, K.J.; et al. A novel pathogenic role of the ER chaperone GRP78/BiP in rheumatoid arthritis. J. Exp. Med. 2012, 209, 871-886. [CrossRef] [PubMed]

172. Connor, A.M.; Mahomed, N.; Gandhi, R.; Keystone, E.C.; Berger, S.A. TNFalpha modulates protein degradation pathways in rheumatoid arthritis synovial fibroblasts. Arthritis Res. Ther. 2012, 14, 62. [CrossRef] [PubMed]

173. Laukens, D.; Devisscher, L.; Van den Bossche, L.; Hindryckx, P.; Vandenbroucke, R.E.; Vandewynckel, Y.P.; Cuvelier, C.; Brinkman, B.M.; Libert, C.; Vandenabeele, P.; et al. Tauroursodeoxycholic acid inhibits experimental colitis by preventing early intestinal epithelial cell death. Lab. Invest. 2014, 94, 1419-1430. [CrossRef] [PubMed]

174. Van den Bossche, L.; Hindryckx, P.; Devisscher, L.; Devriese, S.; Van Welden, S.; Holvoet, T.; Vilchez-Vargas, R.; Vital, M.; Pieper, D.H.; Vanden Bussche, J.; et al. Ursodeoxycholic Acid and Its Taurine- or Glycine-Conjugated Species Reduce Colitogenic Dysbiosis and Equally Suppress Experimental Colitis in Mice. Appl. Environ. Microbiol. 2017, 83. [CrossRef]

175. Wang, W.; Zhao, J.; Gui, W.; Sun, D.; Dai, H.; Xiao, L.; Chu, H.; Du, F.; Zhu, Q.; Schnabl, B.; et al. Tauroursodeoxycholic acid inhibits intestinal inflammation and barrier disruption in mice with non-alcoholic fatty liver disease. Br. J. Pharmacol. 2018, 175, 469-484. [CrossRef]

176. Kim, B.J.; Arai, Y.; Park, E.M.; Park, S.; Bello, A.; Han, I.B.; Lee, S.H. Osteogenic Potential of Tauroursodeoxycholic Acid as an Alternative to rhBMP-2 in a Mouse Spinal Fusion Model. Tissue Eng. Part A 2018, 24, 407-417. [CrossRef]

177. Arai, Y.; Choi, B.; Kim, B.J.; Rim, W.; Park, S.; Park, H.; Ahn, J.; Lee, S.H. Tauroursodeoxycholic acid (TUDCA) counters osteoarthritis by regulating intracellular cholesterol levels and membrane fluidity of degenerated chondrocytes. Biomater. Sci. 2019, 7, 3178-3189. [CrossRef]

178. Levine, B.; Kroemer, G. Autophagy in the pathogenesis of disease. Cell 2008, 132, 27-42. [CrossRef]

179. Choi, A.M.; Ryter, S.W.; Levine, B. Autophagy in human health and disease. N. Engl. J. Med. 2013, 368, 651-662. [CrossRef]

180. Rioux, J.D.; Xavier, R.J.; Taylor, K.D.; Silverberg, M.S.; Goyette, P.; Huett, A.; Green, T.; Kuballa, P.; Barmada, M.M.; Datta, L.W.; et al. Genome-wide association study identifies new susceptibility loci for Crohn disease and implicates autophagy in disease pathogenesis. Nat. Genet. 2007, 39, 596-604. [CrossRef]

181. Cadwell, K.; Liu, J.Y.; Brown, S.L.; Miyoshi, H.; Loh, J.; Lennerz, J.K.; Kishi, C.; Kc, W.; Carrero, J.A.; Hunt, S.; et al. A key role for autophagy and the autophagy gene Atg1611 in mouse and human intestinal Paneth cells. Nature 2008, 456, 259-263. [CrossRef] [PubMed]

182. Adolph, T.E.; Tomczak, M.F.; Niederreiter, L.; Ko, H.J.; Bock, J.; Martinez-Naves, E.; Glickman, J.N.; Tschurtschenthaler, M.; Hartwig, J.; Hosomi, S.; et al. Paneth cells as a site of origin for intestinal inflammation. Nature 2013, 503, 272-276. [CrossRef] [PubMed]

183. Lin, N.Y.; Chen, C.W.; Kagwiria, R.; Liang, R.; Beyer, C.; Distler, A.; Luther, J.; Engelke, K.; Schett, G.; Distler, J.H. Inactivation of autophagy ameliorates glucocorticoid-induced and ovariectomy-induced bone loss. Ann. Rheum. Dis. 2016, 75, 1203-1210. [CrossRef] [PubMed]

184. Ma, Y.; Qi, M.; An, Y.; Zhang, L.; Yang, R.; Doro, D.H.; Liu, W.; Jin, Y. Autophagy controls mesenchymal stem cell properties and senescence during bone aging. Aging Cell 2018, 17, 12709. [CrossRef] [PubMed] 
185. Luo, P.; Gao, F.; Niu, D.; Sun, X.; Song, Q.; Guo, C.; Liang, Y.; Sun, W. The Role of Autophagy in Chondrocyte Metabolism and Osteoarthritis: A Comprehensive Research Review. Biomed. Res. Int. 2019, 2019, 5171602. [CrossRef] [PubMed]

186. Arai, A.; Kim, S.; Goldshteyn, V.; Kim, T.; Park, N.H.; Wang, C.Y.; Kim, R.H. Beclin1 Modulates Bone Homeostasis by Regulating Osteoclast and Chondrocyte Differentiation. J. Bone Miner. Res. 2019, 34, 1753-1766. [CrossRef] [PubMed]

187. Xiao, L.; Xiao, Y. The Autophagy in Osteoimmonology: Self-Eating, Maintenance, and Beyond. Front. Endocrinol. 2019, 10, 490. [CrossRef]

188. Wu, S.; Zhang, Y.G.; Lu, R.; Xia, Y.; Zhou, D.; Petrof, E.O.; Claud, E.C.; Chen, D.; Chang, E.B.; Carmeliet, G.; et al. Intestinal epithelial vitamin D receptor deletion leads to defective autophagy in colitis. Gut 2015, 64, 1082-1094. [CrossRef]

189. Ip, W.K.E.; Hoshi, N.; Shouval, D.S.; Snapper, S.; Medzhitov, R. Anti-inflammatory effect of IL-10 mediated by metabolic reprogramming of macrophages. Science 2017, 356, 513-519. [CrossRef]

190. Shi, X.; Chen, Q.; Wang, F. Mesenchymal stem cells for the treatment of ulcerative colitis: A systematic review and meta-analysis of experimental and clinical studies. Stem Cell Res. Ther. 2019, 10, 266. [CrossRef]

191. Sylvester, F.A.; Wyzga, N.; Hyams, J.S.; Gronowicz, G.A. Effect of Crohn's disease on bone metabolism in vitro: A role for interleukin-6. J. Bone Miner. Res. 2002, 17, 695-702. [CrossRef] [PubMed]

192. Fournier, B.M.; Parkos, C.A. The role of neutrophils during intestinal inflammation. Mucosal Immunol. 2012, 5, 354-366. [CrossRef] [PubMed]

193. Neurath, M.F. Cytokines in inflammatory bowel disease. Nat. Rev. Immunol. 2014, 14, 329-342. [CrossRef] [PubMed]

194. Friedrich, M.; Pohin, M.; Powrie, F. Cytokine Networks in the Pathophysiology of Inflammatory Bowel Disease. Immunity 2019, 50, 992-1006. [CrossRef] [PubMed]

195. Wallace, K.L.; Zheng, L.B.; Kanazawa, Y.; Shih, D.Q. Immunopathology of inflammatory bowel disease. World J. Gastroenterol. 2014, 20, 6-21. [CrossRef] [PubMed]

196. Trottier, M.D.; Irwin, R.; Li, Y.; McCabe, L.R.; Fraker, P.J. Enhanced production of early lineages of monocytic and granulocytic cells in mice with colitis. Proc. Natl. Acad. Sci. USA. 2012, 109, 16594-16599. [CrossRef] [PubMed]

197. Desalegn, G.; Pabst, O. Inflammation triggers immediate rather than progressive changes in monocyte differentiation in the small intestine. Nat. Commun. 2019, 10, 3229. [CrossRef]

198. Oostlander, A.E.; Everts, V.; Schoenmaker, T.; Bravenboer, N.; van Vliet, S.J.; van Bodegraven, A.A.; Lips, P.; de Vries, T.J. T cell-mediated increased osteoclast formation from peripheral blood as a mechanism for Crohn's disease-associated bone loss. J. Cell. Biochem. 2012, 113, 260-268. [CrossRef]

199. Schirmer, M.; Smeekens, S.P.; Vlamakis, H.; Jaeger, M.; Oosting, M.; Franzosa, E.A.; Ter Horst, R.; Jansen, T.; Jacobs, L.; Bonder, M.J.; et al. Linking the Human Gut Microbiome to Inflammatory Cytokine Production Capacity. Cell 2016, 167, 1125-1136. [CrossRef]

200. Ohlsson, C.; Nigro, G.; Boneca, I.G.; Backhed, F.; Sansonetti, P.; Sjogren, K. Regulation of bone mass by the gut microbiota is dependent on NOD1 and NOD2 signaling. Cell. Immunol. 2017, 317, 55-58. [CrossRef]

201. Hernandez, C.J.; Guss, J.D.; Luna, M.; Goldring, S.R. Links Between the Microbiome and Bone. J. Bone Miner. Res. 2016, 31, 1638-1646. [CrossRef] [PubMed]

202. Collins, F.L.; Rios-Arce, N.D.; Atkinson, S.; Bierhalter, H.; Schoenherr, D.; Bazil, J.N.; McCabe, L.R.; Parameswaran, N. Temporal and regional intestinal changes in permeability, tight junction, and cytokine gene expression following ovariectomy-induced estrogen deficiency. Physiol. Rep. 2017, 5, 13263. [CrossRef] [PubMed]

203. Irwin, R.; Lee, T.; Young, V.B.; Parameswaran, N.; McCabe, L.R. Colitis-induced bone loss is gender dependent and associated with increased inflammation. Inflamm. Bowel Dis. 2013, 19, 1586-1597. [CrossRef] [PubMed]

204. Thayu, M.; Shults, J.; Burnham, J.M.; Zemel, B.S.; Baldassano, R.N.; Leonard, M.B. Gender differences in body composition deficits at diagnosis in children and adolescents with Crohn's disease. Inflamm. Bowel Dis. 2007, 13, 1121-1128. [CrossRef] [PubMed]

(C) 2019 by the authors. Licensee MDPI, Basel, Switzerland. This article is an open access article distributed under the terms and conditions of the Creative Commons Attribution (CC BY) license (http://creativecommons.org/licenses/by/4.0/). 